University of Zurich

Department of Economics

Working Paper Series

ISSN 1664-7041 (print)

ISSN 1664-705X (online)

Working Paper No. 382

\title{
Leading with the (Recently) Successful? Performance Visibility and the Evolution of Risk Taking
}

Sönke Ehret, Sonja Vogt, Andreas Hefti and Charles Efferson

April 2021 


\section{Leading with the (Recently) Successful? \\ Performance Visibility and the Evolution of Risk Taking}

Sönke Ehret ${ }^{a, b}$ (sonkeklaus.ehret@unil.ch), Sonja Vogt ${ }^{b}$ (sonja.vogt@unibe.ch), Andreas Hefti ${ }^{c}$ (andreas.hefti@uzh.ch), Charles Efferson ${ }^{a}$ (charles.efferson@unil.ch)

${ }^{a}$ HEC Lausanne

${ }^{b}$ University of Bern

${ }^{c}$ ZHAW School of Management and Law and University of Zürich

\section{Corresponding Authors:}

Sönke Ehret and Charles Efferson

HEC Lausanne, Quartier de Chambronne, Internef 261, 1015 Lausanne

Email: sonkeklaus.ehret@unil.ch, charles.efferson@unil.ch

Declarations of interest: none 


\begin{abstract}
The popular practice of "leading by the successful" is viewed as a hallmark of motivational leadership. A central rationale for leaders to make successful team members salient is that it may induce social learning, where followers strive to adopt a favorable behavior. The reliance of a leader on such successbiased social learning presumes that imitation by followers occurs only to the extent as outstanding success was caused by a superior ability or knowledge of the respective peer. In this article, we conduct a laboratory experiment to study whether imitation of the successful may occur even if imitation necessarily fails to be an effective way of improving one's performance. The experimental approach establishes the necessary control to assure that successbiased learning cannot systematically improve the decisions made, and allows us to isolate the behavior of the followers from possible feedback effects of the leader. The data show that a substantial amount of imitation occurs, which in our setting leads to a sizeable and persistent increase of the average risk taken in the teams. Our finding thus indicates a limitation of the practice to lead with the successful.
\end{abstract}

Keywords: social learning, laboratory experiments, motivational leadership 
"Imitation is not just the sincerest form of flattery - it's the sincerest form of learning." — George Bernard Shaw

\section{Introduction}

Learning from successful peers is frequently regarded as an effective way to increase one's own success. By imitating the best, the members of a team may benefit from the knowledge of successful team members (Gigerenzer and Brighton, 2009; Venkitachalam and Busch, 2012). Ultimately, this insight culminates into the leadership practice of deliberately making successful strategies visible (Szulanski, 1996, Seidlerde Alwis and Hartmann, 2008; Garvin, Edmondson and Gino, 2008). This idea of "leading with the successful" has found wide recognition as part of a leader's toolkit for managing a team. In this respect, practical literature emphasizes the positive role that praise and recognition of top performers play for motivating other team members (Gostick and Elton, 2009; Podsakoff et al., 2006), advises to make performance transparent as an effective strategy for leaders (Daghfous, 2004, Dewhurst, Guthridge and Mohr, 2009), and generally recommends peer learning as a powerful way of improving team performance Argote, 1999; Goh, 2002; Palmer and Blake, 2018; Darino and Williams, 2019).

Such motivational leadership practices have a counterpart in the literature on cultural evolution or evolutionary psychology, where observing and imitating successful individuals is regarded as a powerful way of acquiring useful information (Jiménez and Mesoudi, 2019; Henrich and Gil-White, 2001; Baldini, 2012; Bandura, 1962, 1977). Imitation is likely to be effective, if success is the consequence of a systematic tendency to perform well within a common decision environment. By contrast, if success of a top performer largely results from good fortune, rather than from some form of superior ability or knowledge, imitation may fail to improve the imitator's 
success. Moreover, imitation may then have adverse effects if a successful outcome is mis-attributed to other aspects than luck (Jones and Harris, 1967; Denrell and Fang, 2010) $\cdot^{1}$

Attending preferentially to successful individuals could prevail, even if success is a consequence of luck. This possibility suggests a conceivable limitation in the strategy to lead with the successful, in particular, if success-biased learning is a persistent trait among team members. Can a leader, who chooses to lead with the most successful, rely on the team members to avoid imitating success when imitation fails to improve success? Or will imitation prevail, potentially leading to unintended consequences for the organization's culture? Does such adverse and unintended imitation depend on team compositions, e.g., in terms of demographic characteristics, or on dynamic properties of the environment, such as "prospering" or "receding" times?

In this article, we study whether success-biased behavior emerges in teams if success is both made salient to all team members but also a sheer consequence of luck. Imitation therefore cannot improve the likelihood of one's success. To study this question, we implement a tightly controlled laboratory experiment Antonakis et al., 2010; Podsakoff and Podsakoff, 2019), where we use investment decisions under uncertainty as the incentivized choices that need to be made by the participants.

In the experiment, individual investment choices in each of 45 identical periods can only influence the riskiness of the choices, but not the expected return of the chosen investments. Importantly, choices cannot affect the likelihood of success in any period - successful results are purely stochastic outcomes which are independent

\footnotetext{
${ }^{1}$ Variants of the mis-attribution problem can be found in success-breeds-success dynamics when positive feedback bestows success on the already successful (van de Rijt et al. 2014), or if undersampling of failure leads to a selective focus on success (Denrell | 2003). Likewise, Kirchler, Lindner and Weitzel (2018) find evidence of non-salutary organizational ranking effects on risk taking (Kirchler, Lindner and Weitzel, 2018).
} 
and identically distributed over all periods. Because our setup assures that any investment's outcome depends solely on luck, imitating other investors can only affect the risk borne by one's investment decisions, but it cannot systematically increase the expected return of the investment strategy. The experimental instructions and procedure make sure that these aspects are commonly known to all subjects before the experiment starts.

To study whether success-biased behavior emerges as a consequence of leading with the successful, we randomly partition the subjects into groups of 6 members. At the end of each period, we display the investment decision and the success of the most successful group member to all group members. In our experiment, this procedure systematically selects the subjects who take the highest risks with their decisions. Success-biased behavior occurs if group members respond to this social information by increasing their own risk-taking in their subsequent decisions. To test whether the resulting behavioral pattern is driven by the association of risk-taking with success, we compare it to a control treatment, where the least successful group member is displayed. This procedure assures that both treatments identically select the subjects bearing the highest risks, but only one of the treatment associates this risk-seeking with success.

Our wider contribution is to provide a controlled empirical assessment of the consequences of operational leadership strategies (Judge, 2004; Eagly, JohannesenSchmidt and van Engen, 2003; Antonakis, Avolio and Sivasubramaniam, 2003, Antonakis et al., 2010; Podsakoff and Podsakoff, 2019, Eisenkopf, 2020). There is a growing interest in understanding the limitations and constraints motivational leadership can face. When can such leadership backfire? Often, empirical researchers face a dilemma. Leaders implement a strategy, followers respond, and then leaders respond in turn by adjusting their strategy. The feedbacks in both directions can 
confound the empiricist attempting to isolate the effects of the original leadership strategy. To overcome this problem, we test our predictions using laboratory experiments. The experimental setup allows us to control a leader's choice of strategies to make success visible, and solely analyse the actions of followers as a response. Using such an experiment thus allows us to identify causally the limitations leaders face when they employ strategies meant to motivate individuals. In this respect, our data point towards a limitation of leadership strategies aimed at motivating followers by endorsing a comparison with the successful, if success is of a coincidental nature. Moreover, the experimental approach allows to exogenously vary the economic conditions, simulating, e.g., the experience of a "boom" or a "bust", enabling us to study whether success-biased behavior is prone to, or resilient against dynamically changing conditions.

Finally, our article contributes to the literature on evolutionary informed scholarship. Our research highlights the importance of understanding persistent traits and behavioral tendencies of followers. Prior research suggests an evolutionary basis for leadership-followership relations, based on leader cues, such as competence and performance (Van Vugt and Grabo, 2015; Bastardoz and Van Vugt, 2019). We also include the effects of different demographic predictors of success-biased learning into our analysis, which closely follows current research on individual heterogeneity in social learning and its cultural evolutionary consequences (Molleman, van den Berg and Weissing, 2014; Mesoudi et al., 2016). Given this potential heterogeneity, we further investigate how it can inform a leader's decision about whether or not to make success visible to followers.

\section{Experimental Design and Procedure}

In this section we outline the experimental design and procedure. 


\subsection{Individual Choices}

Our experiment consisted of 45 identical rounds, designed as investment decisions. In each round, an individual had to allocate a total of 20 indivisible tokens on two sides (Left and Right); see Figure 7 in the Appendix for a screenshot. All 20 tokens had to be allocated. After all subjects allocated their tokens, the computer randomly determined a winning side, where either Left or Right was chosen with equal probability. The selected side yielded a return $G>1$ per token invested on that side, while the other side paid a return of 0.5 per invested token. We refer to $G$ as the "win factor", and a dynamically changing value of $G$ was part of our treatment variations.

The investment task was designed such that, by choosing a token allocation, subjects effectively choose how much risk to take with their investments. Placing 10 tokens on each side corresponds to the risk-free allocation. The more tokens are placed on one side, the more risky the allocation becomes. The maximally risky allocation is to place all 20 tokens on the same side. Importantly, the chosen allocation exclusively affects the risk undertaken but not the expected return - every possible allocation had the same expected value of $10 G+5$ tokens..$^{2}$

\subsection{Groups and Treatments}

Before the experiment started, subjects were randomly partitioned into groups of 6 members. All groups stayed constant during the entire experiment, and the computer determined a common winning side for all members in a group at the end of each round. These groups can be conceived as a workplace team, where all mem-

\footnotetext{
${ }^{2}$ Define $c_{i t} \in\{0,1, \ldots, 20\}$ as the number of tokens allocated to the right by $i$ in $t$. By extension, $20-c_{i t}$ is the number allocated to the left. Let $X_{t}$ be a random variable with support $\{0,1\}$ and realizations $x_{t}$ such that $X_{t}=0$ indicates that left was optimal in $t$, and $X_{t}=1$ indicates that right was optimal. The payoff for $i$ in $t$ is thus, $\pi_{i t}=\left(1-x_{t}\right)\left(G\left(20-c_{i t}\right)+\frac{c_{i t}}{2}\right)+x_{t}\left(\frac{20-c_{i t}}{2}+G c_{i t}\right)$. Importantly, participants could not increase their expected return on investment. The design implies the same expected value irrespective of the allocation choice. The perfect diversification in this setup is to invest 10 tokens into both the right and left project, minimizing the risk incurred.
} 
bers make individual economic decisions over time, but face a common economic environment.

At the end of each period, we reported a member's investment decision and payoff from the previous round to all members of the group, while visualizing their choice of allocating tokens into the Right and Left sides (see Figure 8 in the Appendix for a screenshot). Our main treatment variation was whether the reported member was the most or least successful group member in the prior period. That is, in one treatment, we reported the member who achieved the highest payoff in the previous period, while we reported the member who achieved the lowest payoff in the other treatment (see Figure 8 in the Appendix for a screenshot) $!^{3}$ Treatments were randomly assigned across groups and did not change for the entire duration of a session. For simple reference, we refer to the treatment displaying the best (worst) performer as the "Most Successful" ("Least Successful") treatment, respectively.

To become most successful in a group, one had to take a lot of risk and get lucky. To become least successful in the group, one had to take a lot of risk and get unlucky. Thus, in both treatments, we effectively selected the most extreme risk takers and made their choices visible. The key difference is that in one case a risky allocation profile was presented with the highest realized success while in the other case a similar risky allocation profile was presented with the lowest realized success. Note that neither success nor failure of the displayed group member can be indicative of any superior skill or knowledge, as all draws were independent and identically distributed, and all allocations yield the same expected return.

Previous research has shown that the economic conditions experienced by the subjects can have substantial implications on the evolution of risk-seeking over time.

\footnotetext{
${ }^{3}$ If there was more than one individual who received the highest / lowest payoff in a group, the computer broke ties randomly.
} 
For example, Malmendier and Nagel (2009) find that the experience of a contracting economy with low returns is correlated with later risk avoidance. By contrast, booms seem to trigger positive expectations which drive investment behaviour (Cohn et al. 2015). For such reasons, we conducted three treatment variations, where $G$ either increased over time, remained stable, or decreased over time. These three variations either represent an expanding economy, a stagnant economy or a contracting economy. We refer to these treatments as the Increasing, Stable or Decreasing Trend treatments, respectively. In the increasing regime, $G$ increases step-wise from 1.5 to 8.5 over the 45 periods in intervals of three periods, with increments of 0.5 each. In the stable regime, $G$ is constant with $G=5$. In the decreasing regime, $G$ declines from 8.5 to 1.5 . We implemented these three profitability trends by randomly assigning whether $G$ is increasing, stable, or decreasing to the groups. All members of a group face the same $\mathrm{G}$ in a given period.

All in all, this yields a $2 \times 3$-design with the Most and Least Successful treatments on one side and the three profitability trend treatments on the other side. In total, we conducted 6 experimental sessions with 35 groups, and we recruited 210 subjects from a large Swiss research university $\left.\right|^{4}$ Subjects are paid for one randomly drawn period. The exchange rate was 0.65 Swiss Franc for 1 token earned.

\section{Main Hypotheses}

Our main conjecture is based on the premise that subjects behave according to selective social learning, meaning that they are inclined to imitate a behavior that has previously led to success. In our experiment, however, subjects cannot learn an ability or a decision rule that systematically improves their performance, they can only imitate the degree of risk taking (which we refer to as a risk profile). The core

\footnotetext{
${ }^{4} 5$ sessions had 6 groups, and 1 session 5 groups. The data was collected in the first half of 2014.
} 
of our hypothesis is that success-biased subjects imitate the reported risk profile if they correlate risk taking with success. Our two main treatments both display the most extreme risk takers within a group, but their risk-seeking was associated with success only in the Most Successful treatment. Thus, if our conjecture is correct, we should necessarily be able to observe an overall increase in risk-seeking within groups in the Most Successful treatment relative to the Least Successful treatment. This is summarized in our main hypothesis.

(H1) Risk-seeking is higher in the Most Successful treatment than in the Least Successful treatment.

Economic trend effects yield an additional piece of evidence relative to our key conjecture. Specifically, booms and busts added the experience of being exposed to rising or declining reported maximum payoffs. This exposure can be thought of as increasing or decreasing the salience of the reported maximum payoff over time. Therefore, we expect success-biased behavior to foster risk-seeking in the Increasing Trend treatment given that the reported subject is the most successful decision maker.

(H2) Given that the most successful subjects are reported, risk-seeking is larger in the Increasing than in the Stable Trend treatment.

In case of declining economic trends, success becomes less salient over time. Therefore, we expect to observe less risk-seeking in the Decreasing Trend treatment relative to the Stable Trend treatment (and, by implication, also relative to the Increasing Trend treatment).

(H3) Given that the most successful subjects are reported, risk-seeking is smaller in the Decreasing than in the Stable Trend treatment (and smaller than in the Increasing Trend treatment). 
Note that hypotheses $\mathrm{H} 2$ and $\mathrm{H} 3$ are centered around the possible effects of the economic trend on risk-seeking through its effect of making success visible, as this constitutes the focus of our study. In terms of hypothesis generation, we remain agnostic about the possible effects of trends on risk-seeking that may arise without social learning (Cohn et al., 2015).

\section{Results}

In this section, we present and discuss the main experimental findings. Section 4.1 defines the two measures of risk we use in Section 4.2 to test our main hypotheses. Section 4.3 considers the effect of individual-level characteristics in the context of our key conjectures.

\subsection{Measurements of Risk}

Our experimental design yields a simple measure of risk-seeking based on the individual token allocations. Let $c_{i t}$ denote subject $i$ 's number of tokens invested on Left in period $t$, such that $20-c_{i t}$ are the number of tokens invested on Right. Then, we use the variance of the allocation $\left(c_{i t}, 20-c_{i t}\right)$, defined by

$$
\text { VarAllocation }=\frac{1}{2}\left(c_{i t}-10\right)^{2}+\frac{1}{2}\left(\left(20-c_{i t}\right)-10\right)^{2}=\left(c_{i t}-10\right)^{2}
$$

as our main measure of risk-seeking $!^{5}$ Thus, risk-seeking is minimal if $c_{i t}=10$, and is increasing the less balanced the allocation of the tokens is. Further, we use the absolute difference between $c_{i t}$ and $20-c_{i t}$

$$
\text { DiffAllocation }=\left|c_{i t}-\left(20-c_{i t}\right)\right|=2\left|c_{i t}-10\right|
$$

\footnotetext{
${ }^{5}$ Note that VarAllocation simply is the scale-free version of the variance of the payoffs induced by the lottery $X=\left(c_{i t}, 20-c_{i t}\right)$, as $\operatorname{Var}(X)=\left(10-c_{i t}\right)^{2}(G-0.5)^{2}$.
} 
as an alternative risk measure. While both measures provide the same ordinal ranking of riskiness, the former is more sensitive to the effects related to extreme allocations, while the latter is more sensitive to effects related to intermediate allocations.

\subsection{Risk-Seeking: Main Treatment Effects}

We test our main hypotheses using a standard linear regression framework with the above measures of riskiness as dependent variables. Specifically, we estimate equations of the form

$$
y_{i g t}=X_{i t} \alpha+Z_{g t} \beta+\epsilon_{i g}
$$

where $y$ is either VarAllocation or DiffAllocation, $i$ indicates a subject belonging to group $g, t$ indicates the round, $Z$ is a vector of treatment dummies and $X$ is a specification-depending vector of control variables. We use a small number of demographic control variables, which have been previously associated with risky investment behavior, especially in tasks that involve social learning. These controls are age (Mata et al., 2011), gender (Charness and Gneezy, 2012, dummy variable with male=1), and income (Camerer and Hogarth, 1999).6 Finally, we estimate bootstrapped standard errors with clustering at the group level in all our regressions. Specifically, we use several standard methods of deriving such standard errors, and report the most conservative ones in this article.7 In the Appendix, we provide variable definitions in Table 3 , and general summary statistics in Tables 4 and 5 . Table 6 summarizes the various correlations between treatments and demographic covariates.

\footnotetext{
${ }^{6}$ Our main regression results turn out to be insensitive to these controls. As expected, our treatment assignment is statistically balanced on gender, income and age; see Table 5 in the Appendix.

${ }^{7}$ We estimate clustered standard errors with three different methods, Sandwich, Pairs, and Wild cluster bootstrap (Cameron, Gelbach and Miller, 2008, 2011) - estimates are reported in the Appendix. We report the Pairs Boostrap errors, which are based on re-sampling the clusters with replacement.
} 
Our leading hypothesis is that risk-seeking should be higher in the Most Successful than in the Least Successful treatment. The following result reports the outcome of a regression that compares average risk-seeking between the Most and the Least Successful treatment, pooling the data across all three trend regimes.

Result 1 Averaged across all trend regimes, the allocation variance is 11.6 points higher in the Most Successful than in the Least Successful treatment ( $p=0.011)$. Likewise, the allocation difference is 2.5 tokens larger in the Most Successful than in the Least Successful treatment $(p<0.01)$. This shows that average risk-seeking increases in the Most Successful relative to the Least Successful treatment, consistent with hypothesis $H 1$.

We emphasize that this result holds independent of the control variables. In Appendix 7.5 we present additional evidence supporting our main hypothesis - that social learning fosters risk-seeking if risk-seeking is associated with success. In particular, we exclude that the treatment effect is driven by a decrease in average risk-seeking in the Least Successful condition. In fact, we find that risk-seeking increased in both treatments during the experiment, but significantly and substantially more so in the Most Successful treatment.

Table 1 presents a fine-grained regression analysis, where we differentiate between all 6 treatment variations. Specifically, we define a treatment dummy for each combination of the two dimensions: Stable, Decreasing or Increasing Trend, and Least or Most successful treatment. In Table 1, we use the "Least Successful and Stable Trend" treatment as the omitted category. The Table consists of 6 similar estimations, differing only in the included control variables. Table 1 shows various conditional treatment effects, depending on the profitability regime. With respect to our main hypothesis, Table 1 shows that for the Increasing and Stable Trend treatment separately, risk-seeking significantly increases in the Most Successful treatment com- 
pared to the Least Successful treatment. For the Decreasing Trend regime, however, we find no evidence for a statistical difference between risk-seeking in the Most and Least Successful treatments. These observations are confirmed by Table 2, which uses DiffAllocation as the dependent variable instead.

Table 1: Variance of Allocation

\begin{tabular}{|c|c|c|c|c|c|c|}
\hline & \multicolumn{6}{|c|}{ DV: VarAllocation } \\
\hline & Model 1 & Model 2 & Model 3 & Model 4 & Model 5 & Model 6 \\
\hline Least successful, decreasing & $\begin{array}{c}8.01 \\
(6.77)\end{array}$ & $\begin{array}{c}9.22 \\
(7.45)\end{array}$ & $\begin{array}{c}9.37 \\
(7.31)\end{array}$ & $\begin{array}{c}9.03 \\
(7.44)\end{array}$ & $\begin{array}{c}8.32 \\
(7.05)\end{array}$ & $\begin{array}{c}9.22 \\
(7.37)\end{array}$ \\
\hline Least successful, increasing & $\begin{array}{c}10.90^{* *} \\
(4.73)\end{array}$ & $\begin{array}{l}11.04^{*} \\
(6.20)\end{array}$ & $\begin{array}{c}11.58^{* *} \\
(5.63)\end{array}$ & $\begin{array}{l}10.85^{*} \\
(5.83)\end{array}$ & $\begin{array}{c}11.35^{* *} \\
(5.22)\end{array}$ & $\begin{array}{l}11.04^{*} \\
(5.90)\end{array}$ \\
\hline Most successful, stable & $\begin{array}{c}22.97^{* * *} \\
(8.62)\end{array}$ & $\begin{array}{c}22.74^{* *} \\
(9.49)\end{array}$ & $\begin{array}{c}23.31^{* *} \\
(9.65)\end{array}$ & $\begin{array}{c}22.55^{* *} \\
(9.48)\end{array}$ & $\begin{array}{c}23.42^{* * *} \\
(8.79)\end{array}$ & $\begin{array}{c}22.74^{* *} \\
(9.57)\end{array}$ \\
\hline Most successful, decreasing & $\begin{array}{c}8.31 \\
(5.43)\end{array}$ & $\begin{array}{c}7.80 \\
(6.34)\end{array}$ & $\begin{array}{c}8.43 \\
(5.54)\end{array}$ & $\begin{array}{c}8.15 \\
(6.05)\end{array}$ & $\begin{array}{c}8.31 \\
(5.56)\end{array}$ & $\begin{array}{c}7.80 \\
(5.89)\end{array}$ \\
\hline Most successful, increasing & $\begin{array}{c}25.85^{* * *} \\
(7.38)\end{array}$ & $\begin{array}{c}25.79^{* * *} \\
(7.30)\end{array}$ & $\begin{array}{c}26.24^{* * *} \\
(6.89)\end{array}$ & $\begin{array}{c}25.73^{* * *} \\
(7.44)\end{array}$ & $\begin{array}{c}26.13^{* * *} \\
(7.32)\end{array}$ & $\begin{array}{c}25.79^{* * *} \\
(7.46)\end{array}$ \\
\hline Age & $\begin{array}{l}-0.17 \\
(0.62)\end{array}$ & & $\begin{array}{c}0.31 \\
(0.65)\end{array}$ & & & \\
\hline Gender & $\begin{array}{c}4.37 \\
(3.35)\end{array}$ & & & $\begin{array}{c}4.88 \\
(3.58)\end{array}$ & & \\
\hline Money & $\begin{array}{c}0.01^{* *} \\
(0.004)\end{array}$ & & & & $\begin{array}{c}0.01^{* *} \\
(0.004)\end{array}$ & \\
\hline Period & $\begin{array}{c}0.10 \\
(0.06)\end{array}$ & & & & & $\begin{array}{c}0.10 \\
(0.06)\end{array}$ \\
\hline Constant & $\begin{array}{c}8.12 \\
(12.54)\end{array}$ & $\begin{array}{c}15.97^{* * *} \\
(5.34)\end{array}$ & $\begin{array}{c}8.69 \\
(13.58)\end{array}$ & $\begin{array}{c}13.04^{* *} \\
(5.34)\end{array}$ & $\begin{array}{l}9.32^{* *} \\
(4.15)\end{array}$ & $\begin{array}{c}13.74^{* * *} \\
(5.11)\end{array}$ \\
\hline
\end{tabular}

Note:

${ }^{*} \mathrm{p}<0.1 ;{ }^{* *} \mathrm{p}<0.05 ;{ }^{* * *} \mathrm{p}<0.01$

Standard errors clustered at group level, 1st period omitted

We next turn to the effects of an increasing or decreasing trend on risk-seeking, relative to a Stable Trend, if the most successful subject is reported. Together, hypotheses $\mathrm{H} 2$ and $\mathrm{H} 3$ predict a clear ranking, where most (least) risk-seeking should be observed in the Increasing (Decreasing) Trend treatment. The data from Tables 1 and 2 support this conjecture in part, as summarized in the next result.

Result 2 When the most successful subject is reported, risk-seeking is 15.4 variance points higher in the Stable Trend treatment than in the Decreasing Trend treatment 
Table 2: Difference of Allocation

\begin{tabular}{|c|c|c|c|c|c|c|}
\hline & \multicolumn{6}{|c|}{ DV: DiffAllocation } \\
\hline & Model 1 & Model 2 & Model 3 & Model 4 & Model 5 & Model 6 \\
\hline Least successful, decreasing & $\begin{array}{c}1.41 \\
(1.57)\end{array}$ & $\begin{array}{c}1.66 \\
(1.72)\end{array}$ & $\begin{array}{c}1.66 \\
(1.75)\end{array}$ & $\begin{array}{c}1.64 \\
(1.70)\end{array}$ & $\begin{array}{c}1.51 \\
(1.59)\end{array}$ & $\begin{array}{c}1.66 \\
(1.65)\end{array}$ \\
\hline Least successful, increasing & $\begin{array}{l}2.20^{* *} \\
(1.05)\end{array}$ & $\begin{array}{l}2.31^{*} \\
(1.20)\end{array}$ & $\begin{array}{l}2.31^{*} \\
(1.24)\end{array}$ & $\begin{array}{l}2.30^{*} \\
(1.20)\end{array}$ & $\begin{array}{l}2.36^{* *} \\
(1.09)\end{array}$ & $\begin{array}{l}2.31^{*} \\
(1.24)\end{array}$ \\
\hline Most successful, stable & $\begin{array}{l}4.48^{* * *} \\
(1.70)\end{array}$ & $\begin{array}{l}4.53^{* *} \\
(1.89)\end{array}$ & $\begin{array}{l}4.53^{* *} \\
(1.79)\end{array}$ & $\begin{array}{l}4.51^{* *} \\
(1.90)\end{array}$ & $\begin{array}{l}4.64^{* *} \\
(1.84)\end{array}$ & $\begin{array}{l}4.53^{* *} \\
(1.92)\end{array}$ \\
\hline Most successful, decreasing & $\begin{array}{c}1.90^{*} \\
(1.10)\end{array}$ & $\begin{array}{c}1.96 \\
(1.22)\end{array}$ & $\begin{array}{c}1.96 \\
(1.27)\end{array}$ & $\begin{array}{c}1.99 \\
(1.22)\end{array}$ & $\begin{array}{l}2.05^{*} \\
(1.21)\end{array}$ & $\begin{array}{c}1.96 \\
(1.24)\end{array}$ \\
\hline Most successful, increasing & $\begin{array}{c}5.26^{* * *} \\
(1.39)\end{array}$ & $\begin{array}{c}5.33^{* * *} \\
(1.42)\end{array}$ & $\begin{array}{c}5.33^{* * *} \\
(1.37)\end{array}$ & $\begin{array}{c}5.33^{* * *} \\
(1.41)\end{array}$ & $\begin{array}{c}5.39^{* * *} \\
(1.34)\end{array}$ & $\begin{array}{c}5.33^{* * *} \\
(1.45)\end{array}$ \\
\hline Age & $\begin{array}{l}-0.09 \\
(0.11)\end{array}$ & & $\begin{array}{c}0.0004 \\
(0.13)\end{array}$ & & & \\
\hline Gender & $\begin{array}{c}0.28 \\
(0.71)\end{array}$ & & & $\begin{array}{c}0.39 \\
(0.71)\end{array}$ & & \\
\hline Money & $\begin{array}{l}0.002^{* *} \\
(0.001)\end{array}$ & & & & $\begin{array}{l}0.002^{* *} \\
(0.001)\end{array}$ & \\
\hline Period & $\begin{array}{l}0.001 \\
(0.01)\end{array}$ & & & & & $\begin{array}{c}0.001 \\
(0.01)\end{array}$ \\
\hline Constant & $\begin{array}{c}6.04^{* * *} \\
(2.20)\end{array}$ & $\begin{array}{c}5.39^{* * *} \\
(1.08)\end{array}$ & $\begin{array}{l}5.38^{* *} \\
(2.73)\end{array}$ & $\begin{array}{c}5.15^{* * *} \\
(1.11)\end{array}$ & $\begin{array}{c}4.32^{* * *} \\
(0.91)\end{array}$ & $\begin{array}{c}5.36^{* * *} \\
(1.19)\end{array}$ \\
\hline
\end{tabular}

$(p<0.1)$, and 18.5 variance points higher in the Increasing Trend treatment than in the Decreasing Trend treatment $(p<0.01)$. A similar pattern holds for allocation differences, which is consistent with Hypothesis H3. For the Increasing Trend treatment compared to the Stable Trend treatment, we don't find evidence (H2) for a significant increase of risk-seeking (3.1 variance points, $p=0.73$ ).

The weak evidence for a positive effect of the Increasing Trends treatment (H2) may be in part due to a weak substitution effect between the treatment effect of providing information on the most successful, and a direct effect of increasing trends on risk taking. Additional exploratory evidence suggests that participants reacted to the salience of success in the predicted direction but also that Increasing Trends increased risk taking in the Least Successful information treatment more so than in the Most Successful information treatment, where information about strong success 
was already present. 8 Tables 1 and 2 further show that, compared to the Stable Trend - Least Successful treatment, risk-seeking does not change with a decreasing trend, even if the most successful subjects are reported. Together with our previous results, this suggests an asymmetric role for information about success. When success became more salient, either because the highest success was selectively reported, or alternatively, because the magnitude of reported success increased over time, the evidence of our experiment shows an increase in risk-seeking. By contrast, if the magnitude of reported success decreased over time, or the least successful subjects were displayed, risk-seeking of the reported member seemed not to be imitated.

We also run the previous regressions by controlling for general time effects. In Model 6 of Tables 2 and 1, we include the respective period of the investment task into the estimation. This allows us to control for a possibly increasing experience of the subjects with the experiment over time. Including such a time trend has no effect on the treatment estimates, not even in the Stable Trend treatment, where experienced-based learning is perhaps most likely to appear. Furthermore, including a subject-specific linear time trend to control for individual time effects (e.g., due to individual-level learning), has also no effect on the treatment estimates.

In the Appendix, we summarize the estimates of a more sophisticated model that groups together consecutive periods and interacts period with the demographic controls.9 This result confirms that time (or experience) seem to play no decisive role for our main treatment effects.

\footnotetext{
${ }^{8}$ In the Least successful information treatment, Increasing Trends increased risk taking by 11.05 variance points $(p=0.054)$, compared to Stable Trends. The overall treatment effect of Most Successful information compared to Least Successful information is then 8.0 variance points less (not significant, $p=0.47)$ in the Increasing Trends treatment $(15.1$ variance points, $p<0.05)$ than in the Stable Trends treatment (23.1 variance points, $p<0.05)$.

${ }^{9}$ See Tables 7 and 8 in the Appendix.
} 


\subsection{The Effects of Individual Characteristics}

We established our main findings regarding the effects of social learning on riskseeking by controlling for gender, age and income, as these factors have been previously related to risk attitudes. This analysis, focusing on average treatment effects, did not address whether demographic characteristics matter for individual decisions, while previous research has pointed to possible gender and age effects in social learning (Mesoudi et al., 2016; Lind and Lindenfors, 2010; Berl and Hewlett, 2015). For this reason, we conducted a subgroup analysis that exploits the in-sample variation of gender and age to study if differential effects arise once the most successful subject is made visible. We also include income as a potential variable to affect success-biased social learning. Obtaining such insights is of relevance for the literature on team composition and performance management Webber and Donahue, 2001; Kozlowski and Bell, 2003; Jackson and Joshi, 2004). So far, this literature has found mixed evidence regarding the role of gender, age or income of the followers for effective leadership in case of heterogeneously composed teams. In this respect, our data allows us to explore whether these demographic variables matter through a social learning channel.

We study whether gender, age or income have a differential impact on individual risk-seeking, given that either the best or worst performing subject is displayed to a group, by estimating a fully saturated model, including all interaction effects between gender, age and income with the 6 treatments. Figure 1 visualizes some of the average marginal effects derived from the full model, which can be found in the Appendix $\sqrt{10}$ We discuss the main insights of the detailed analysis below, where all reported numbers about risk are based on VarAllocation (DiffAllocation yields similar results).

\footnotetext{
${ }^{10}$ Figure 1 refers to Table 7 , model (7).
} 
As a summative preview, we find some evidence for heterogeneous effects, which intuitively supports that social learning is a relevant driving force behind our treatment effects. Moreover, heterogeneity seems relevant for understanding when teams may abandon imitation of the best, or adopt it. In particular, the evidence indicates that more mature individuals and a mix of genders can decrease a team's tendency to imitate the most successful individuals, at least when success is not a signal for ability. We emphasize that our data does not allow to interpret the possible effects of the demographic variables in a causal way. Nevertheless, we think that studying the effect of group compositions, as a major treatment variable, might be a promising avenue for future research, on how the effectiveness of leading with the successful may be mitigated by different ways of learning in teams.

\subsubsection{Gender}

Prior research has found that, depending on the domain and society, gender can sometimes moderate social learning, but the evidence in general is inconclusive (Mesoudi, 2011; Lind and Lindenfors, 2010; Demps, 2012). With respect to riskseeking, the existing literature commonly finds men to bear more risk than women (see, e.g., Charness and Gneezy, 2012; Niederle and Vesterlund, 2007), emphasizing a higher competitiveness of men. Our experimental data allows us to test whether risk-seeking is larger for men in the context of social learning and, in addition, whether this effect changes conditional on improving or deteriorating economic conditions.

Our main question of interest is if men and women responded differently in their risk-seeking depending on whether the social information displays success or failure as a consequence of risk-taking. The data shows a versatile picture. Averaged across all economic trend treatments, the data does not support that displaying the most successful group member relative to the least successful member induced a differen- 
tial effect for men and women. However, a more fine-grained analysis suggests that this finding results from opposed forces, depending on the exact trend condition, as explained in the next paragraph.

Men displayed significantly more risk-seeking if they see the most successful group member, relative to seeing the least successful member, in the Increasing and Stable Trend treatments. Specifically, risk-seeking increases by 20 variance points $(p<0.05)$ from 27 to 47 points in the Increasing Trend treatment, and by 27 points $(p<0.01)$ from 14 to 41 points in the Stable Trend treatment. By contrast, we do not find that women showed a statistically significant increase of their risk-seeking in these treatments. In the Decreasing Trend treatment, however, the evidence suggests that the role of gender is inverted. In this treatment, men reduced their risk seeking by 14 points $(p<0.05)$ from 32 to 18 , while women increased their riskseeking by 18 points $(p<0.01)$ from 12 to 30 points.

In sum, the evidence suggests a difference for the tendency to react to reported success between men and women. This difference is conditional on whether reported success increases or decreases over time. Based on our data, we would thus expect teams consisting mostly of males to show a particularly pronounced rise in riskseeking if reported success does not diminish over time. By contrast, observing a diminishing success of the most successful member seems to make the same team cut back on its exposure to risk. For a team consisting mostly of women however, risk taking would be less susceptible to increasing or decreasing reported successes.

\subsubsection{Age}

Previous experimental evidence indicates that younger people seem to be more prone to social learning effects (Mesoudi et al., 2016, Berl and Hewlett, 2015). In particular, there appears to be a trend towards more individual learning in adulthood, 


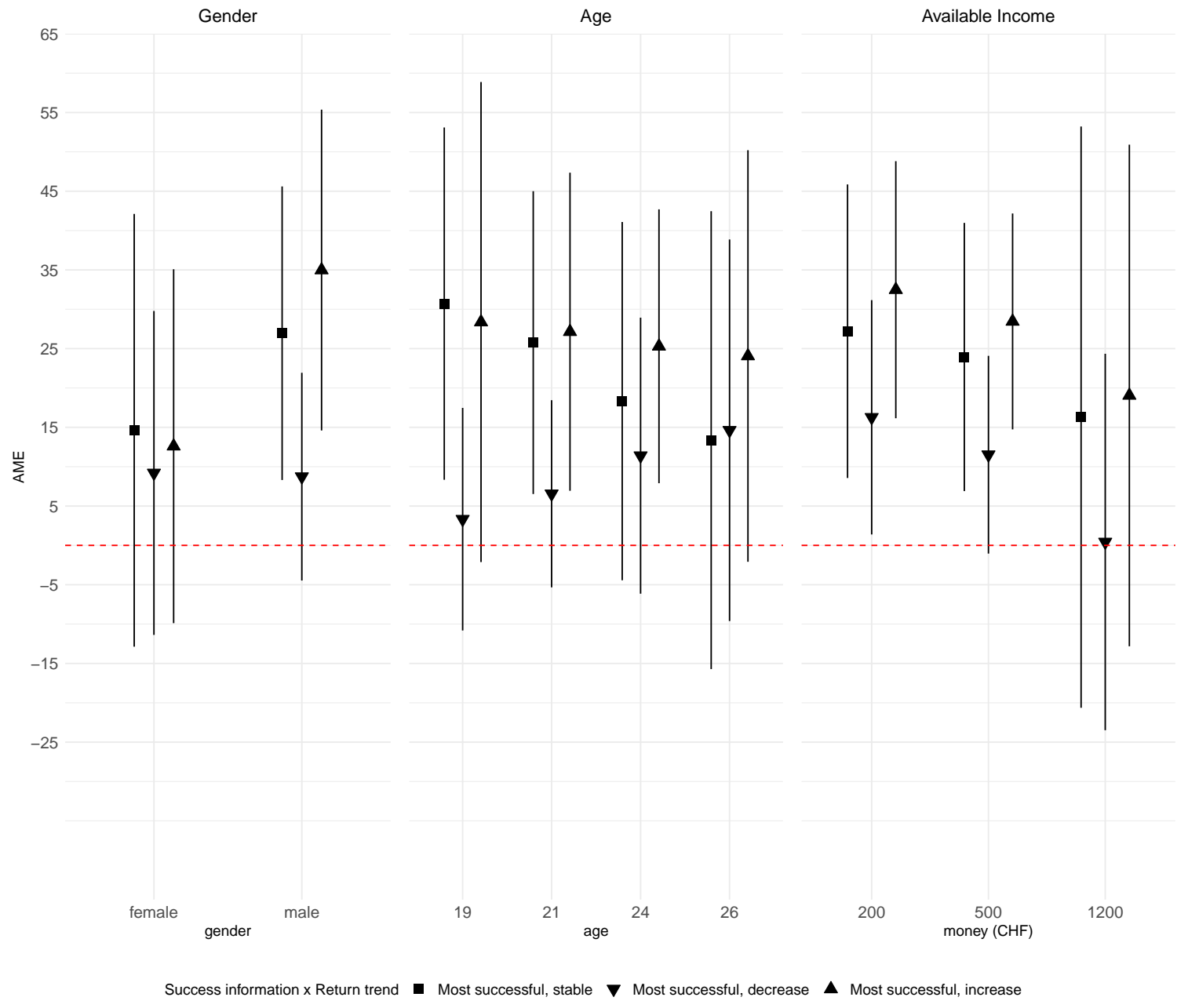

Figure 1: Average marginal effects of the information treatment at different covariate values of the fully saturated interaction model in column (7) of Table 7 in the Appendix. Omitted category: stable, least successful manipulation. Differences between regime trend effects are additive relative to the omitted category. Each cell represents the estimated treatment effect at the covariate values on the $\mathrm{x}$-axis, holding the other covariates their mean. Bars represent $95 \%$ CIs derived with bootstrapped clustering at the level of a group. 
away from peer-based learning in adolescence. This observation is relevant as most subjects are in between adolescence and adulthood in our student sample.

To assess whether younger subjects exert more social learning, we partitioned the subjects into various age groups. Our data remains modestly inconclusive about the effects of age. In particular, we do not find a statistically significant difference between the main treatment effects for the various age groups. Nevertheless, the data does indicate a rough tentative trend effect of age consistent with a diminished importance of social learning with emerging adulthood (Mesoudi et al., 2016), at least for the stable and increasing trend conditions. As Figure 1 shows, the treatment effect is significantly larger than zero at younger age, but eventually becomes indistinguishable from zero at older age. At age 21, which is the median age in the sample, the average marginal treatment effect is 25.8 variance points in the stable regime $(p<0.01)$. At the 80 th percentile age of 24 , the effect is 18.3 points $(p=0.12)$, for the 90 th percentile at age 26 it is $13.4(p=0.4)$.

\subsubsection{Income}

In incentivized experiments involving risk taking, the participants' levels of disposable income may have conflicting effects. On the one side, subjects with higher disposable income may be more prone to accepting gambles, for example, if they are more affected by "house money" effects (Thaler and Johnson, 1990). In this sense, one could expect subjects with higher income to display more risk-seeking behavior, or at least pay more attention to decisions involving risks. On the other side, wealthier subjects may respond less to experimental incentives (Camerer and Hogarth, 1999), with ambiguous effects on a preferential bias to learn about successful projects.

To assess the effect of disposable income in the context of our main treatment 
variable, we proceed similar to Age, and partition the self-reported income measure into decile groups. As depicted in the right panel of Figure 1, the evidence indicates that the level of income may indeed affect the relationship between top performance visibility and risky investment choices. Specifically, top performance information is positively associated with risk-seeking for individuals with lower disposable income. At the 10th percentile income (200 CHF), the treatment effect is 27.2 points in the stable regime $(p<0.01)$, while it decreases to 16.3 points at the 90 th percentile (1200 CHF), which is not significantly different from zero $(p=0.43)$. A similar pattern applies for the other trend conditions as well. This finding suggests that income may affect risk-taking through a social learning channel. In particular, a simple explanation that wealthier students tended to take more risk cannot account for the previous pattern. However, it is conceivable that wealthier subjects might have paid less attention to successful outcomes in the investment task, which reduced the amount of social learning, too.

\section{$5 \quad$ Imitation and Persistence of Risk-Seeking}

In this section, we investigate the behavior of the followers in greater detail. In a first step, we study how group members learned in the experiment. In a second step, we assess how risk-seeking evolves dynamically over time.

\subsection{Imitation of the Allocation or the Risk Profile?}

Social learning can take place in different ways in our experiment. On the one hand, subjects could simply copy the exact allocation of the displayed individual, which also has the effect of increasing risk-seeking. If subjects merely imitated the observed allocation, the choice made by an observer should be positively correlated with the choice she observed in the previous period. If such behavior is a dominating trait, we should find that groups choose more often to allocate their tokens, e.g., on Right 
given that the reported subject previously allocated a majority of tokens on Right.

On the other hand, subjects could imitate the observed risk profile, i.e., the imbalance of the displayed token allocation, independent from which of the two projects was actually favored by the displayed individual. If the subjects imitated the risk profile, rather than the allocation, we should find a positive relation between the variances of the observers' and the displayed subject's allocations, but not necessarily between the allocations themselves. A specific explanation consistent with imitating the risk profile but not the specific allocation direction is Gambler's Fallacy. According to Gambler's Fallacy, people should allocate more tokens on the project which did not win in the previous period. That is, if the reported allocation was strongly favoring Left, we should observe a shift in the next period of the allocations towards Right, and vice-versa. Our experimental design allows us to test whether the possible occurrence of Gambler's Fallacy depends on whether the reported risky behavior was successful or not, thereby pointing towards a conceivable moderating role of social learning.

Empirical Results Figures 2 and 3 provide a visual impression of how the allocation between Left and Right was affected by the observed allocation in the previous round. Figure 2 refers to the case of the Most Successful treatment, for all three trend treatments separately. Figure 3 displays the same type of information for the Least Successful treatment. To illustrate the logic of these figures, consider the left panel in Figure 2, which depicts the behavior in the Most Successful - Stable Trend treatment. The horizontal axis groups the possible allocations of the reported individual in various intervals, where negative intervals mean that the reported subjects invested more tokens on Left. For example, the interval $[-20,-15]$ means that a subject invested at least 15 tokens on Left. The vertical axes uses the same intervals, but displays the allocation of the subjects in the subsequent period. The 
size of the black disks expresses the absolute frequency of the respective combination.

If subjects were to imitate the observed allocation, we should see the largest disks in the bottom left and upper right corner, respectively. The figures display vastly different patterns. First, Figure 2 indicates that, in the Most Successful treatments, people tend to respond with extreme allocations (but not always), but these allocations may also favor the opposite field, consistent with the pattern implied by Gambler's Fallacy. Second, there is no pronounced response in terms of extreme allocations in the Least Successful treatments. Rather, subjects seem to have settled their allocations around the middle, consistent with our previous result that risk-seeking is higher in the Most Successful treatment.

Figures 4 and 5 show how the variance of the allocation of the group members (vertical axis) relates to the variance of the reported subject's variance. If people imitated the risk profiles, then we should observe larger disks towards the upper right corners. The figures indeed confirm such a pattern in the Most Successful treatments - most clearly so in the Stable or Increasing trend treatments - but not in the Least Successful treatments. In particular, the fact that a lot of mass is located at the extremes in the Most Successful treatments supports the idea that, for social learning to pick up, the reported individual's choices need to have yielded a sufficiently salient success.

A more rigorous quantitative assessment confirms that, if at all, subjects responded by investing more tokens on the opposite rather than on the same side as the reported group member did (see Table 11 in the Appendix for the regression evidence). The most remarkable piece of evidence is that we only find such behavior to occur in case of the Most Successful treatment. This observation suggests a novel and intriguing possible connection between Gambler's Fallacy and social learning: Social 
learning of the displayed risk seems to arise only if risk-taking was successful, and when social learning arises, people tend to fall victim to Gambler's Fallacy.

The following summarizes the main empirical insights of this section.

Result 3 The data shows that the subjects imitate the risk profile, rather than the allocation, of the previously successful. In addition, we find evidence favoring the occurrence of Gambler's Fallacy. If the displayed successful allocation put most tokens on Left, then the amount of tokens invested on Right in the next period by the observers is significantly larger (and vice-versa), where this effect only arises in the Most Successful treatment.

\subsection{Risk-Seeking Over Time}

Our baseline analysis established the treatment effect by averaging over all periods of play. In this section, we investigate how risk-seeking evolved over time, depending on the treatment conditions. In particular, if risk-seeking increased as a consequence of social learning, we would expect to see evidence indicating a "take-off"-effect in the average behavior. In the first period, subjects had no prior social information, and thus their behavior was not yet affected by social learning. A take-off effect occurs if some subjects begin to ramp up their risk-seeking in response to observing successful risky allocations, which further increases the success of the displayed allocations, inducing even more people to adopt such a behavior.

The caterpillar plots in Figures 6 visualize how average risk-seeking, measured by VarAllocation, increases over time in the Most Successful treatment relative to the Least Successful treatment, for each trend treatment separately ${ }^{11}$ In the figure, each solid dot represents the difference of average risk-seeking between the Most

\footnotetext{
${ }^{11}$ Using DiffAllocation instead yields similar plots.
} 

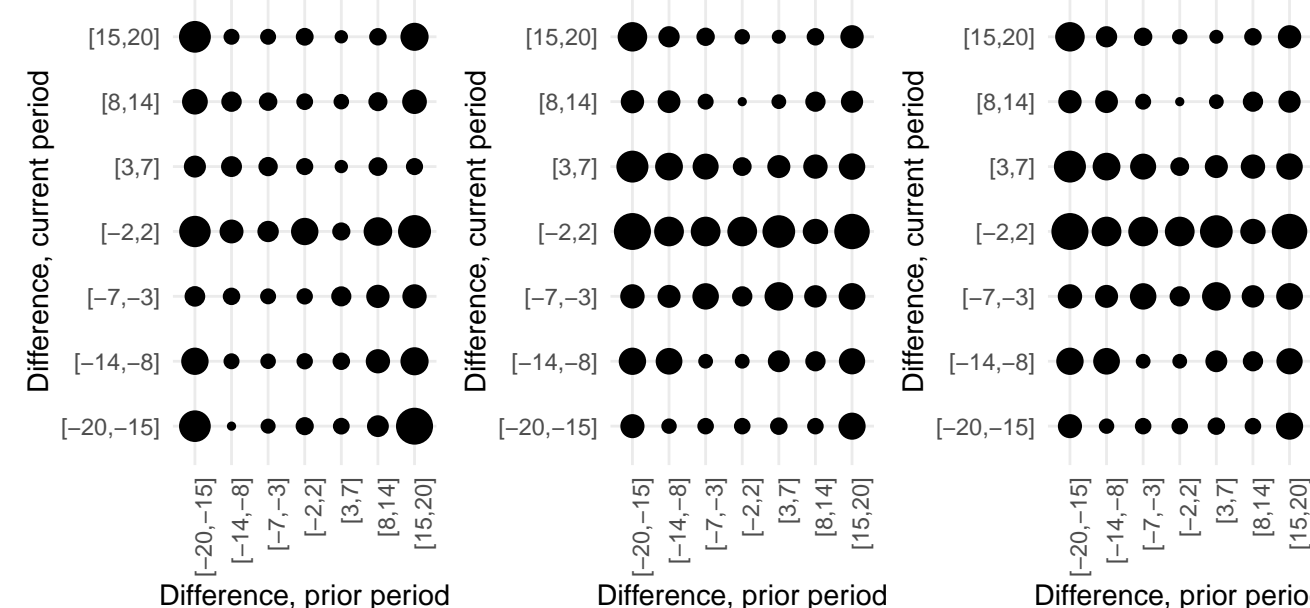

๘

ก)

Difference, prior period

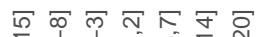
จุป

Difference, prior period

frequency $25 \bigcirc 50 \bigcirc 75 \bigcirc 100$

Figure 2: Matching prior and current period differences of allocation, for best performance information. Horizontal axis intervals denote differences for right minus left project allocation in $t-1$. The vertical axis shows the interval for allocation differences in the period $t$. Disks visualize the counts of cases where the differences of allocation in $t$ and $t-1$ are in the same interval.

stable

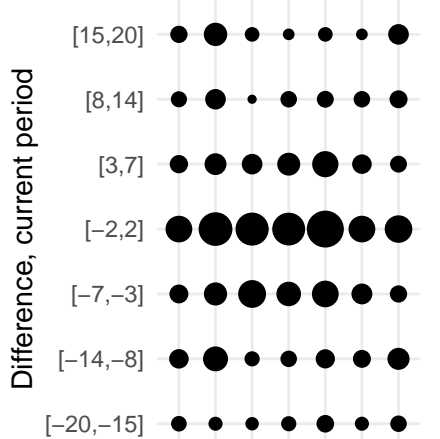



Difference, prior period decreasing

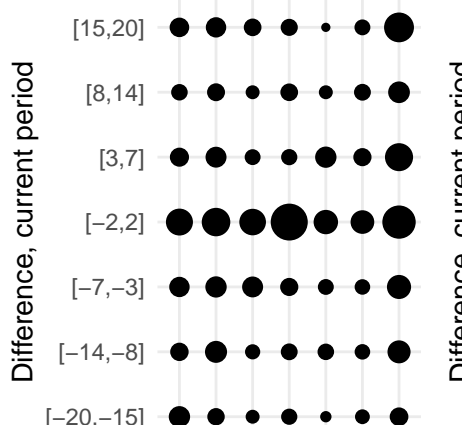

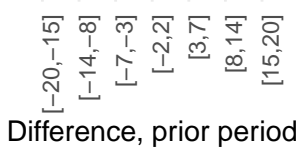

increasing

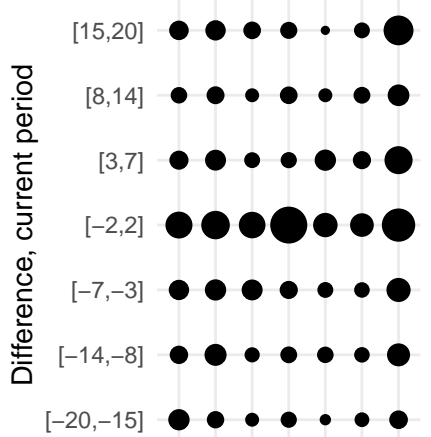


กิ

Difference, prior period

frequency $50 \bigcirc 100 \bigcirc 150$

Figure 3: Matching prior and current period differences of allocation, for worst performance information. Horizontal axis intervals denote differences for right minus left project allocation in $t-1$. The vertical axis shows the interval for allocation differences in the period $t$. Disks visualize the counts of cases where the differences of allocation in $t$ and $t-1$ are in the same interval. 


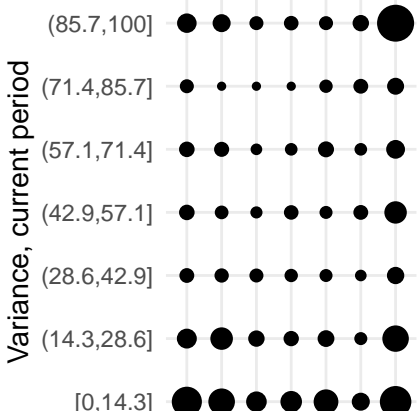

लबन ॠ

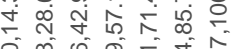

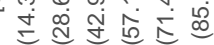
Variance, prior period

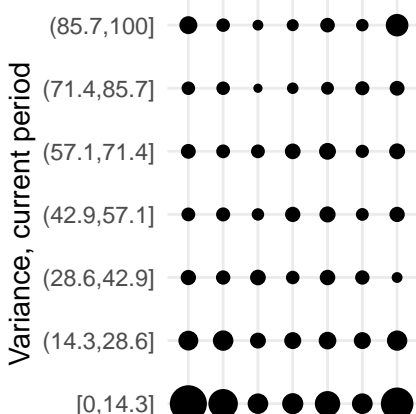

ल $\sigma \mp$ б

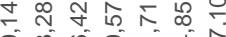

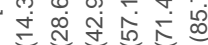
Variance, prior period

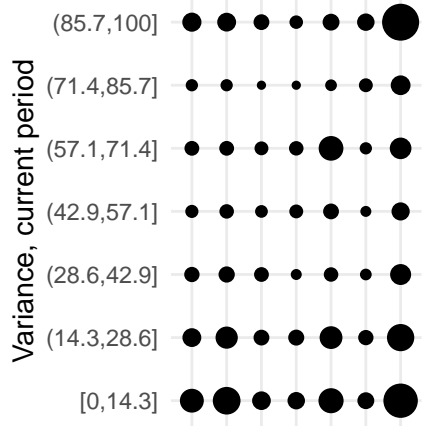

लढ

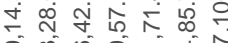

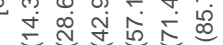
Variance, prior period

frequency

100

200

Figure 4: Matching prior and current period variances of allocation, for best performance information. Horizontal axis intervals denote the variance of allocation in $t-1$. The vertical axis shows the interval for allocation variances in the period $t$. Disks visualize the counts of cases where the variances of allocation in $t$ and $t-1$ are in the same interval.

stable

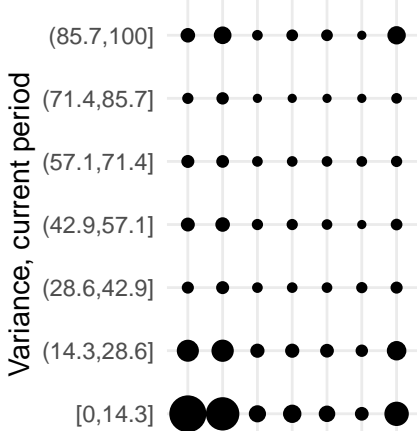

m $\sigma \mp \% 下 \sigma$

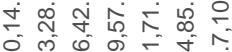

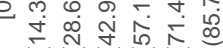

Variance, prior period decreasing

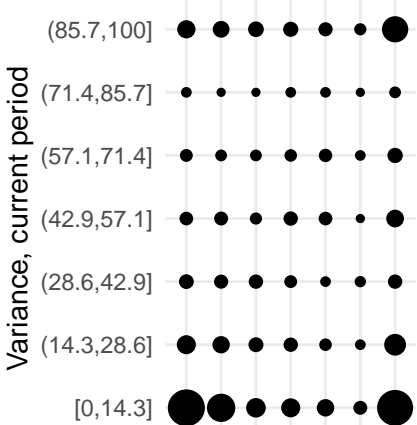

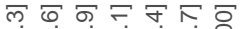

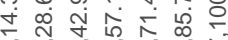

○一

Variance, prior period increasing

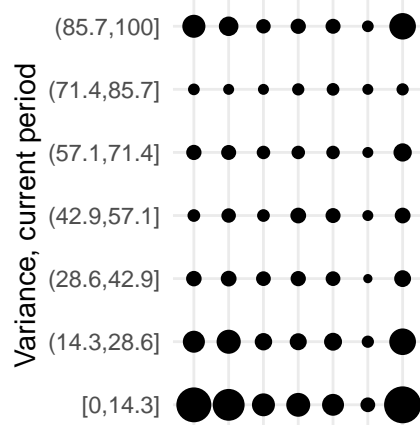

क

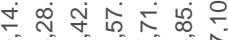

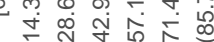

Variance, prior period

$$
\text { frequency } \quad 0 \quad 100200-300
$$

Figure 5: Matching prior and current period variances of allocation, for worst performance information. Horizontal axis intervals denote the variance of allocation in $t-1$. The vertical axis shows the interval for allocation variances in the period $t$. Disks visualize the counts of cases where the variances of allocation in $t$ and $t-1$ are in the same interval. 
and Least Successful treatments up to the current period $t$. Thus, for a positive difference, risk-seeking is larger in the Most than in in the Least Successful treatment for the respective period. The figure shows that, for the stable and the increasing trend, this difference increases steeply during the first periods, consistent with a take-off effect. In addition, the figure indicates that adopted risk-seeking seems to be persistent, that is, the treatment effect is not shifting downwards towards the end of the experiment. This is fairly remarkable as the increased risk naturally means that subjects must eventually have experienced an adverse outcome given the risk they took. Nevertheless, it seems that dismal individual outcomes failed to serve as an effective corrective for individual behavior in a social environment that associates success with risk.

In Section 7.5 of the Appendix, we present regression evidence that further corroborates the above visual impression that risk-seeking increases significantly over time in the Most Successful treatment, and much more so relative to the Least Successful treatment 12

\footnotetext{
${ }^{12}$ In these regressions, we exploit that the first period risk-seeking can serve as a benchmark for a subject's baseline risk-attitude. If social learning affects risk-seeking, then we should be able to observe more risk-seeking of an individual subject relative to her benchmark level in the Most Successful treatment compared to the Least Successful treatment. This provides an alternative way of testing our main hypothesis.
} 


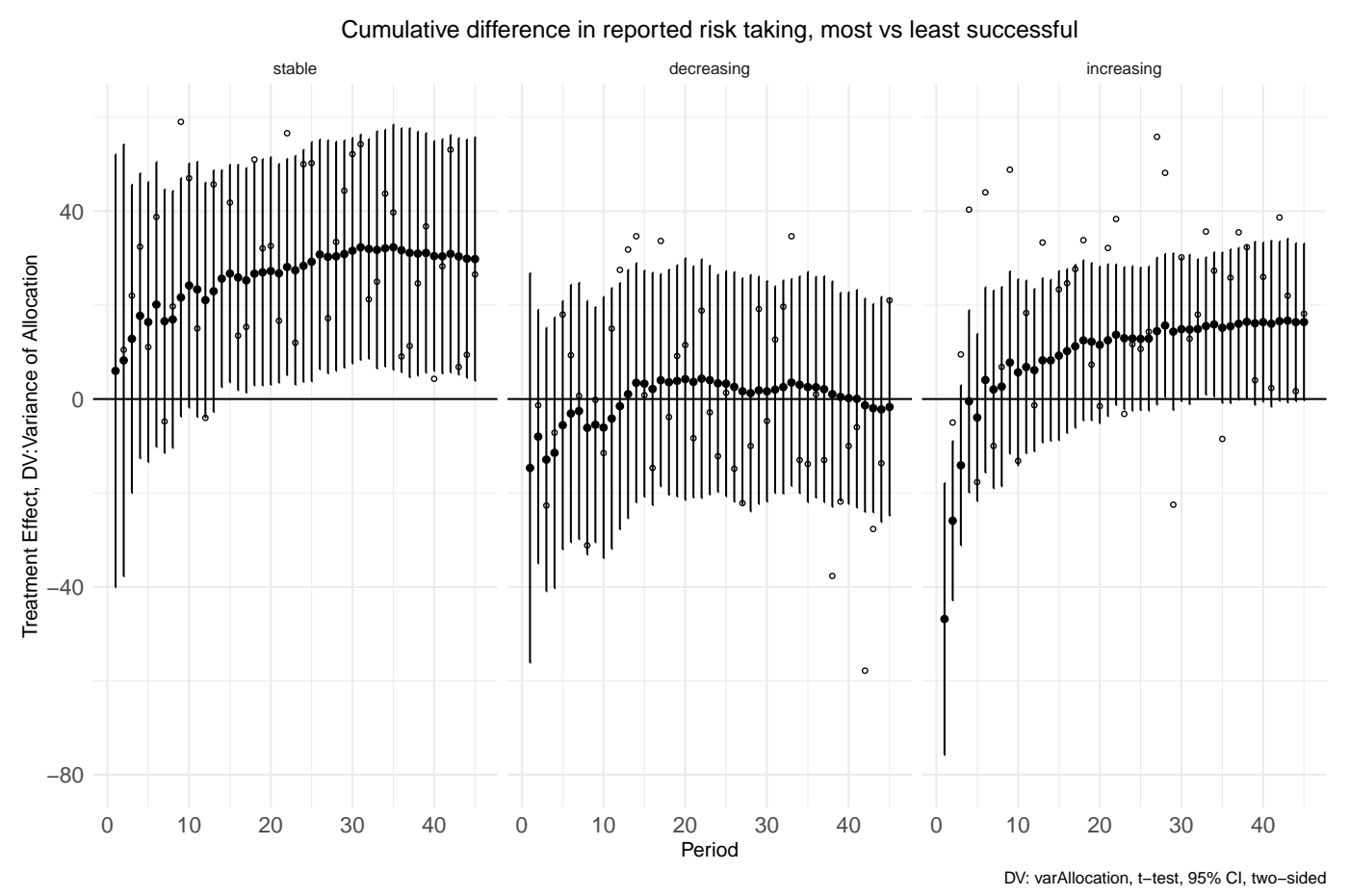

Figure 6: Variance of allocation, cumulative treatment effect. Solid dots show the treatment effect for the most successful information treatment, including all periods up to the given period. Bars are $95 \%$ confidence intervals using bootstrapped groupclustered standard errors. Hollow dots show the per-period treatment effect.

\section{Discussion and Conclusion}

A well-defined leadership strategy largely proves its worth through the responses it evokes among followers. This is especially true for "leading by the successful", which has emerged as a prominent strategy for motivational leadership. One reason why such a leadership practice has propagated is its potential to stimulate social learning. By observing projects which were previously successful, other team members may increase their own success. In particular, this happens if imitation allows these team members to improve their decision making ability, based on what has previously spurred success. In reality, success may involve a substantial amount of coincidence. It may be hard for leaders to identify how much of a successful outcome should be attributed to luck. For example, it is known that financial leaders tend to overly focus on all-stars winners, while discounting actual skill (Denrell and Fang, 2010. 
Groysberg, Healy and Maber, 2011). In such situations, the effectiveness of leading by the successful strongly relies on the followers' ability to identify a possible gap between ability and luck over time, and to adjust their learning strategy accordingly.

This article studies the behavior of followers if a most successful team member is made visible, but success is a consequence of sheer luck. Our laboratory experiment allows us to precisely measure how the individual actions of followers - the riskiness in their investment decisions - evolve over time, and to study how group heterogeneity or changing economic conditions interact with the information presented to the followers. Our data clearly shows that average risk-seeking increases relative to the control group, as well as relative to the first period, where no social information at all is present. Moreover, we can exclude that this difference arises because associating risk-seeking with failure makes subjects resilient against imitation. An increase in risk-seeking, relative to the first period, arises in both cases, but much more so if the displayed high-risk profile is also successful. These findings are particular striking because the experimental procedure made sure that the independent and identically distributed structure of the optimal projects was commonly known to all subjects prior to the start of the experiment.

The empirical evidence gained from our experiment indicates a limitation in the effectiveness of leading with the successful if luck and coincidence play a major role. This limitation points to a challenge for leaders who want to understand the capacity of their team members to learn vicariously. Such learning may evolve in different forms. For example, we find that subjects seem to imitate risk profiles, rather than the precise allocations made by the displayed subjects. In addition, we observe that a behavior consistent with Gambler's Fallacy arises, but only if the most successful project is reported, not when the least successful project is reported. Considering such details is important since our findings do not exclude that - in principle - an 
intelligent use of performance information in groups is possible. As we have shown, individual group members do not just spontaneously copy the choices of successful individuals, but rather, they take aim at the risk profiles they observe, and in some cases, attempt to guess the impending outcome of an investment. This insight points to several avenues of further research, which involve the active role of leaders to foster accurate risk perceptions, promote effective risk communication, and enhance the statistical understanding of their followers (Gigerenzer, 2014, Siegrist and Árvai, 2020).

More generally, our findings have several important implications for leaders. First, simply providing more opportunities to learn may not attenuate the adverse effects of imitating the successful. To the contrary, even if faced with repeated feedback for 45 otherwise identical rounds of decision making, subjects did not abandon the imitation of the successful. Average risk-seeking did not wear off, but rather stabilized at a higher level over the course of the experiment's sessions ${ }^{13}$ This makes increased risk-seeking a persistent phenomenon, and the groups, on average, became more exposed to risk. As a consequence, the likelihood of the extremes substantive success or failure - became larger for such groups. These findings help to understand for example, why information about the best performers, even though well intended in its objective to promote learning, appears to motivate excessive risk taking in financial professionals (Lindner et al., 2019). Future research should examine leadership strategies that provide alternatives to peer learning, for example whether individual learning by trial and error can be effective in situations where the performance of team members strongly depends on coincidence.

A second take-away is the nature of group composition, or the question of who learns from whom within a group is an additional but related important element

\footnotetext{
${ }^{13}$ By controlling for common and subject-specific time trends, we can exclude that such effects are artefacts of repetition or individual learning that is unrelated to the displayed social information.
} 
too. Our experiment shows that group composition can play a vital role. There are individual differences in the extent to which risk-seeking behavior is adopted. For example, women seem to be less sensitive to information about the choices of successful individuals, and younger individuals are more likely to follow social cues. Taken together these findings imply that there are ways a leader can compose teams which are less prone to adopt potentially adverse peer learning cultures, although more research would be needed to test these implications experimentally.

As a third take-away, we also want to highlight that leaders may need to take the economic context of an organization into account. Regarding economic trends, we found a significant information treatment effect if the subjects were either experiencing a stable or an increasing trend environment. In this sense, a leadership strategy that predominantly seeks to motivate by displaying the successful may actually magnify the exuberance sometimes witnessed during economic expansions, compared to economic contractions. We found no significant difference between treatment and control group for decreasing economic trends. More generally, this suggests that both the dynamics of social learning and the size of the perceived differences between one's own situation and the success of others may be important factors to consider in future studies on social learning.

To conclude, the dispersion of information in organizations is a part of an organization's strategy and culture. By managing how useful information is stored, made visible, and disseminated among the individual, leaders can possibly improve the performance of individual team members and of the organization itself. Leading with successful peers can be an effective rule of thumb, but hinges critically on the nuanced psychological details of how people learn from their peers. A psychological followership bias that works well one day can easily lead to unanticipated outcomes the next day. In our study, as a general effect, we found top performance informa- 
tion to trigger persistent peer imitation effects, despite that the success cannot be a result of a systematic tendency to perform well. Therefore, our data sheds doubts on a blunt application of a "leading with the successful" leadership practice. 


\section{References}

Antonakis, John, Bruce J Avolio and Nagaraj Sivasubramaniam. 2003. "Context and leadership: an examination of the nine-factor full-range leadership theory using the Multifactor Leadership Questionnaire." The Leadership Quarterly 14(3):261 295.

URL: http://www.sciencedirect.com/science/article/pii/S1048984303000304

Antonakis, John, Samuel Bendahan, Philippe Jacquart and Rafael Lalive. 2010. "On making causal claims: A review and recommendations." The Leadership Quarterly 21(6):1086 - 1120. Leadership Quarterly Yearly Review.

URL: http://www.sciencedirect.com/science/article/pii/S1048984310001475

Argote, L. 1999. Organizational Learning-Creating, Retaining and Transferring Knowledge. Kluwer Academic, Boston.

Baldini, Ryan. 2012. "Success-biased social learning: cultural and evolutionary dynamics." Theoretical population biology 82:222-8.

Bandura, A. 1977. Social learning theory. Englewood Cliffs, NJ: Prentice Hall.

Bandura, Albert. 1962. Social learning through imitation. Oxford, England: Univer. Nebraska Press pp. 211-274.

Bastardoz, Nicolas and Mark Van Vugt. 2019. "The nature of followership: Evolutionary analysis and review." The Leadership Quarterly 30(1):81 - 95.

URL: http://www.sciencedirect.com/science/article/pii/S1048984317308068

Berl, Richard E. W. and Barry S. Hewlett. 2015. "Cultural Variation in the Use of Overimitation by the Aka and Ngandu of the Congo Basin." PLOS ONE 10(3):120.

URL: https://doi.org/10.1371/journal.pone.0120180 
Camerer, Colin F. and Robin M. Hogarth. 1999. "The Effects of Financial Incentives in Experiments: A Review and Capital-Labor-Production Framework." Journal of Risk and Uncertainty 19(1/3):7-42.

URL: www.jstor.org/stable/41760945

Cameron, A. Colin, Jonah B. Gelbach and Douglas L. Miller. 2008. "BootstrapBased Improvements for Inference with Clustered Errors." The Review of Economics and Statistics 90(3):414-427.

URL: http://www.jstor.org/stable/40043157

Cameron, A. Colin, Jonah B. Gelbach and Douglas L. Miller. 2011. "Robust Inference With Multiway Clustering." null 29(2):238-249.

URL: https://doi.org/10.1198/jbes.2010.07136

Charness, Gary and Uri Gneezy. 2012. "Strong Evidence for Gender Differences in Risk Taking." Journal of Economic Behavior \& Organization 83(1):50 - 58. Gender Differences in Risk Aversion and Competition.

URL: http://www.sciencedirect.com/science/article/pii/S0167268111001521

Cohn, Alain, Jan Engelmann, Ernst Fehr and Michel André Maréchal. 2015. "Evidence for Countercyclical Risk Aversion: An Experiment with Financial Professionals." American Economic Review 105(2):860-85.

URL: https://www.aeaweb.org/articles?id=10.125\%/aer.20131314

Daghfous, Abdelkader. 2004. "Absorptive Capacity and the Implementation of Knowledge-Intensive Best Practices." SAM Advanced Management Journal $69(2): 21-27$.

Darino, Lucia, Marcus Sieberer Arthur Vos and Owain Williams. 2019. Performance management in agile organizations. Technical report Mckinsey.

Demps, K., Zorondo-Rodriguez F. Garcia C.A. Reyes-Garcia V. 2012. "Social learn- 
ing across the life cycle: Cultural knowledge acquisition for honey collection among the Jenu Kuruba, India." Evolution and Human Behavior 33:460-470.

Denrell, Jerker. 2003. "Vicarious Learning, Undersampling of Failure, and the Myths of Management." Organization Science 14(3):227-243.

URL: https://pubsonline.informs.org/doi/abs/10.1287/orsc.14.2.227.15164

Denrell, Jerker and Christina Fang. 2010. "Predicting the Next Big Thing: Success as a Signal of Poor Judgment." Management Science 56(10):1653-1667.

URL: https://doi.org/10.1287/mnsc.1100.1220

Dewhurst, Martin, Matthew Guthridge and Elizabeth Mohr. 2009. "Motivating people: Getting beyond money." Mckinsey Quarterly.

Eagly, Alice H., Mary C. Johannesen-Schmidt and Marloes L. van Engen. 2003. "Transformational, transactional, and laissez-faire leadership styles: a metaanalysis comparing women and men." Psychological bulletin 129:569-91.

Eisenkopf, Gerald. 2020. "Words and deeds - Experimental evidence on leading-byexample." The Leadership Quarterly 31(4):101383.

URL: http://www.sciencedirect.com/science/article/pii/S1048984320300102

Garvin, David A., Amy C. Edmondson and Francesca Gino. 2008. Is Yours a Learning Organization? Technical report Harvard Business Review.

Gigerenzer, Gerd. 2014. Risk Savvy: How to Make Good Decisions. Penguin Publishing Group.

Gigerenzer, Gerd and Henry Brighton. 2009. "Homo Heuristicus: Why Biased Minds Make Better Inferences." Cognitive Science .

Goh, Swee C. 2002. "Managing effective knowledge transfer: an integrative framework and some practice implications." Journal of Knowledge Management $6(1): 23-30(8)$. 
Gostick, Adrian and Chester Elton. 2009. The Carrot Principle: How the Best Managers Use Recognition to Engage Their People, Retain Talent, and Accelerate Performance updated \& Rev. FREE PR.

Groysberg, Boris, Paul M Healy and David A. Maber. 2011. "What Drives Sell-Side Analyst Compensation at High-Status Investment Banks?" Journal of Accounting Research 49(4):969-1000.

URL: $\quad$ https://onlinelibrary.wiley.com/doi/abs/10.1111/j.1475$679 X .2011 .00417 . x$

Henrich, Joseph and Francisco J. Gil-White. 2001. "The evolution of prestige: freely conferred deference as a mechanism for enhancing the benefits of cultural transmission." Evolution and Human Behavior 22(3):165-196.

URL: http://www.sciencedirect.com/science/article/pii/S1090513800000714

Jackson, Susan E. and Aparna Joshi. 2004. "Diversity in social context: a multiattribute, multilevel analysis of team diversity and sales performance." Journal of Organizational Behavior 25(6):675-702.

URL: https://onlinelibrary.wiley.com/doi/abs/10.1002/job.265

Jiménez, Ángel V. and Alex Mesoudi. 2019. "Prestige-biased social learning: current evidence and outstanding questions." Palgrave Communications 5(1):20.

URL: https://doi.org/10.1057/s41599-019-0228-7

Jones, Edward E. and Victor A. Harris. 1967. "The Attribution of Attitudes." Journal of Experimental Social Psychology 3(1):1-24.

Judge, Timothy A. Piccolo, Ronald F. 2004. "Transformational and Transactional Leadership: A Meta-Analytic Test of Their Relative Validity." Journal of Applied Psychology, 89(5), 755-768.

Kirchler, Michael, Florian Lindner and Utz Weitzel. 2018. "Rankings and Risk- 
Taking in the Finance Industry." The Journal of Finance 73(5):2271-2302.

URL: https://onlinelibrary.wiley.com/doi/abs/10.1111/jofi.12701

Kozlowski, Steve W. J. and Bradford S. Bell. 2003. Work groups and teams in organizations. Hoboken, NJ, US: John Wiley \& Sons Inc pp. 333-375.

Lind, Johan and Patrik Lindenfors. 2010. "The Number of Cultural Traits Is Correlated with Female Group Size but Not with Male Group Size in Chimpanzee Communities." PLOS ONE 5(3):1-3.

URL: https://doi.org/10.1371/journal.pone.0009241

Lindner, Florian, Michael Kirchler, Stephanie Rosenkranz and Utz Weitzel. 2019. Social status and risk-taking in investment decisions. Working Papers in Economics and Statistics 2019-07 Innsbruck: .

URL: http://hdl.handle.net/10419/207073

Lonati, Sirio, Bernardo F. Quiroga, Christian Zehnder and John Antonakis. 2018. "On doing relevant and rigorous experiments: Review and recommendations." Journal of Operations Management 64:19 - 40.

URL: http://www.sciencedirect.com/science/article/pii/S027269631830072X

Malmendier, Ulrike and Stefan Nagel. 2009. Depression Babies: Do Macroeconomic Experiences Affect Risk-Taking? Working Paper 14813 National Bureau of Economic Research.

URL: http://www.nber.org/papers/w14813

Mata, Rui, Anika K. Josef, Gregory R. Samanez-Larkin and Ralph Hertwig. 2011. "Age differences in risky choice: a meta-analysis." Annals of the New York Academy of Sciences 1235(22023565):18-29.

URL: https://www.ncbi.nlm.nih.gov/pmc/articles/PMC3332530/

Mesoudi, Alex. 2011. "An experimental comparison of human social learning strate- 
gies: payoff-biased social learning is adaptive but underused." Evolution and Human Behavior 32:334-342.

Mesoudi, Alex, Lei Chang, Sasha R.X. Dall and Alex Thornton. 2016. "The Evolution of Individual and Cultural Variation in Social Learning." Trends in Ecology E Evolution 31(3):215 - 225.

URL: http://www.sciencedirect.com/science/article/pii/S0169534715003237

Molleman, Lucas, Pieter van den Berg and Franz J. Weissing. 2014. "Consistent individual differences in human social learning strategies." Nature Communications $5(1): 3570$.

URL: https://doi.org/10.1038/ncomms4570

Niederle, Muriel and Lise Vesterlund. 2007. "Do Women Shy Away From Competition? Do Men Compete Too Much?*." Q J Econ 122(3):1067-1101.

URL: https://doi.org/10.1162/qjec.122.3.1067

Palmer, Kelly and David Blake. 2018. The Expertise Economy: How the Smartest Companies Use Learning to Engage, Compete, and Succeed. MOBIUS.

Podsakoff, Philip M. and Nathan P. Podsakoff. 2019. "Experimental designs in management and leadership research: Strengths, limitations, and recommendations for improving publishability." The Leadership Quarterly 30(1):11 - 33 .

URL: http://www.sciencedirect.com/science/article/pii/S1048984318304442

Podsakoff, Philip M., William H. Bommer, Nathan P. Podsakoff and Scott B. MacKenzie. 2006. "Relationships between leader reward and punishment behavior and subordinate attitudes, perceptions, and behaviors: A meta-analytic review of existing and new research." Organizational Behavior and Human Decision Processes 99(2):113-142.

Seidler-de Alwis, Ragna and Evi Hartmann. 2008. "The use of tacit knowledge 
within innovative companies: knowledge management in innovative enterprises." Journal of Knowledge Management 12(1):133-147.

Siegrist, Michael and Joseph Árvai. 2020. "Risk Perception: Reflections on 40 Years of Research." Risk Analysis 40(S1):2191-2206.

URL: https://onlinelibrary.wiley.com/doi/abs/10.1111/risa.13599

Szulanski, Gabriel. 1996. "Exploring internal stickiness: Impediments to the transfer of best practice within the firm." Strategic Management Journal 17(S2):27-43. URL: https://onlinelibrary.wiley.com/doi/abs/10.1002/smj.4250171105

Thaler, Richard H. and Eric J. Johnson. 1990. "Gambling with the House Money and Trying to Break Even: The Effects of Prior Outcomes on Risky Choice." Management Science 36(6):643-660.

URL: https://doi.org/10.1287/mnsc.36.6.643

van de Rijt, Arnout, Soong Moon Kang, Michael Restivo and Akshay Patil. 2014. "Field experiments of success-breeds-success dynamics." Proceedings of the $\mathrm{Na}$ tional Academy of Sciences 111(19):6934-6939.

URL: https://www.pnas.org/content/111/19/6934

Van Vugt, Mark and Allen E. Grabo. 2015. "The Many Faces of Leadership: An Evolutionary-Psychology Approach." Current Directions in Psychological Science 24(6):484-489.

URL: https://doi.org/10.1177/0963721415601971

Venkitachalam, Krishna and Peter Busch. 2012. "Tacit knowledge: review and possible research directions." Journal of Knowledge Management 16(2):357-372.

Webber, Sheila Simsarian and Lisa M Donahue. 2001. "Impact of highly and less job-related diversity on work group cohesion and performance: a meta-analysis." Journal of Management 27(2):141 - 162 .

URL: http://www.sciencedirect.com/science/article/pii/S0149206300000933 


\section{Appendix}

\subsection{Summary Statistics}

Variable name

\begin{tabular}{l|l}
\hline Age & Respondent age, in years \\
\hline Gender & Dummy variable, Male: 1. Female: 0 \\
\hline Period & Period number, from 1 to 45 \\
\hline Money & $\begin{array}{l}\text { "How much money do you have available } \\
\text { per month (minus the costs of housing)" } \\
\text { Disposable income in Swiss Franc }\end{array}$ \\
\hline Most successful & $\begin{array}{l}\text { Dummy variable, Treatment with most successful } \\
\text { information: 1. Least successful information: 0 }\end{array}$ \\
\hline Increasing economic trend & $\begin{array}{l}\text { Dummy variable, Treatment with increasing } \\
\text { investment returns: 1. With stable or decreasing } \\
\text { returns: 0 }\end{array}$ \\
\hline Decreasing economic trend & $\begin{array}{l}\text { Dummy variable, Treatment with decreasing } \\
\text { investment returns: 1. With stable or increasing } \\
\text { returns: 0 }\end{array}$
\end{tabular}

Table 3: Variables explanations

\begin{tabular}{lcccccc}
\hline variable & min & max & median & mean & sd & skewness \\
\hline diffAllocation = abs(left-right) & 0 & 20 & 6 & 8.1 & 7.13 & 0.45 \\
varAllocation & 0 & 100 & 9 & 29.1 & 36.04 & 1.07 \\
Payoff & 10 & 170 & 55 & 55.2 & 31.59 & 0.79 \\
Money & 0 & 4000 & 500 & 664.45 & 532.92 & 2.5 \\
Gender (1:m) & 0 & 1 & 1 & 0.61 & 0.49 & -0.45 \\
Age & 17 & 72 & 21 & 22.46 & 5.54 & 5.34 \\
Least successful & 0 & 1 & 0 & 0.49 & 0.5 & 0.06 \\
Left project pays G & 0 & 1 & 0 & 0.48 & 0.5 & 0.06 \\
Number of tokens on left & 0 & 20 & 10 & 10.12 & 5.39 & 0.03 \\
Number of tokens on right & 0 & 20 & 10 & 9.88 & 5.39 & -0.03 \\
Win factor G & 1.5 & 8.5 & 5 & 5 & 1.79 & 0 \\
Decreasing returns & 0 & 1 & 0 & 0.34 & 0.47 & 0.66 \\
Increasing returns & 0 & 1 & 0 & 0.34 & 0.47 & 0.66 \\
Most successful & 0 & 1 & 1 & 0.51 & 0.5 & -0.06 \\
\hline
\end{tabular}

Table 4: Summary Statistics 


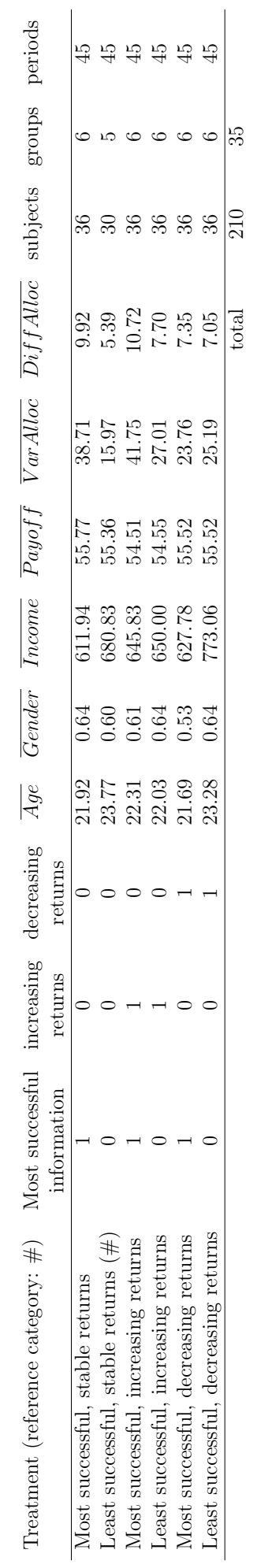

Table 5: Summary Statistics by Manipulation 







\subsection{Screenshots}

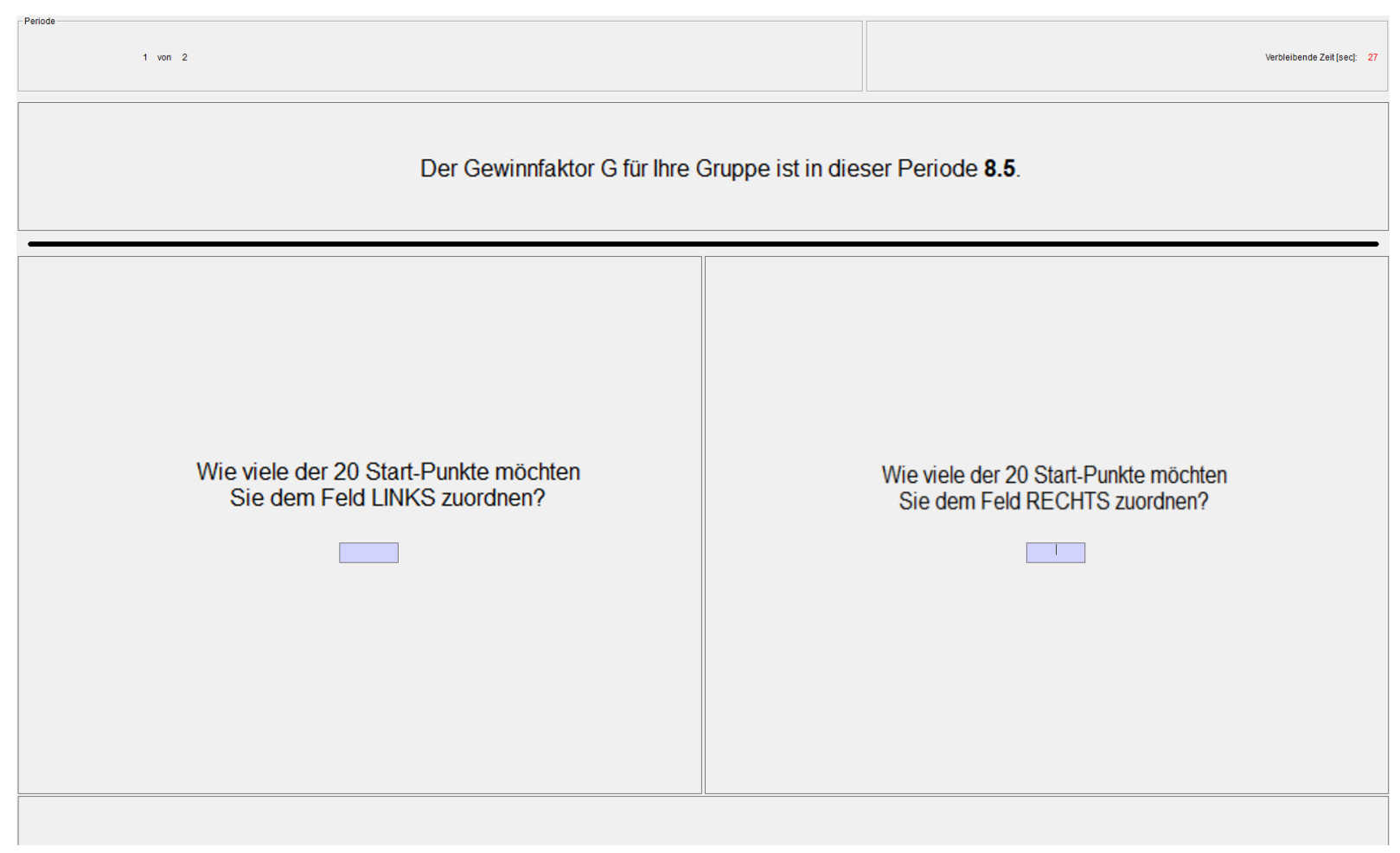

Figure 7: Allocation decision. Screen prompts were presented in German. English translation: a) headline: "The win factor for your group is 8.5 in this period." Left hand side panel: "How many of the 20 starting tokens do you want to allocate to the LEFT field?" Right hand side panel: "How many of the 20 starting tokens do you want to allocate to the RIGHT field?" 


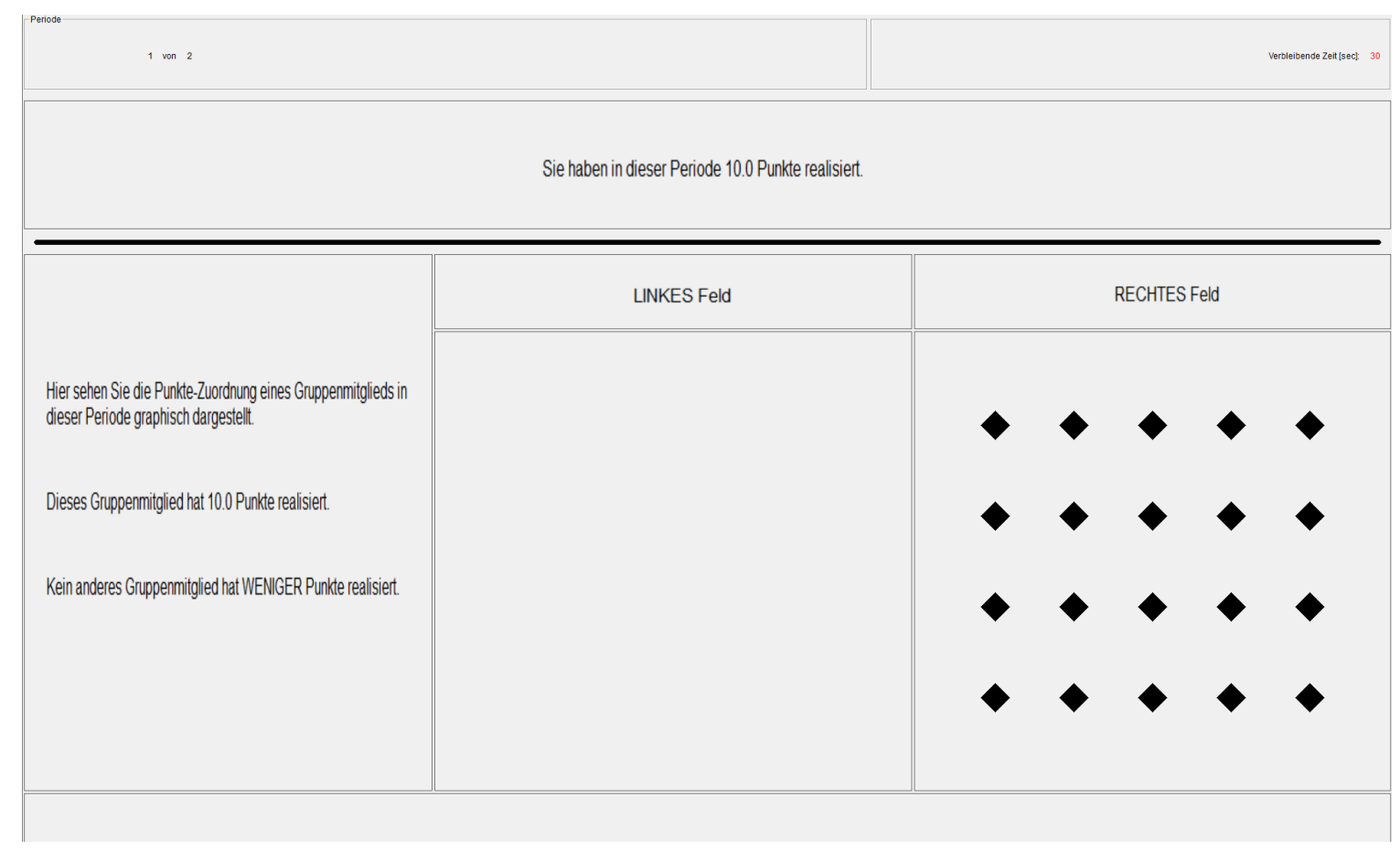

Figure 8: Realization of outcome. Shows tokens invested by reported individual made on left and right side of the screen (graphically depicted). Screen prompts were presented in German. English translation: a) headline: "You have realized 10.0 tokens in this period." Left hand side panel: "Here you can see a graphic display of the point allocation of a group member. This group member has realized 10.0 tokens. No other group member has realized LESS tokens." Model and Right panel header: "LEFT field - RIGHT field". 


\section{Heterogeneity: Interaction Models}

Table 7: Interaction models, bootstrapped clustering

\begin{tabular}{|c|c|c|c|c|c|}
\hline & \multicolumn{5}{|c|}{ DV: VarAllocation } \\
\hline & $\begin{array}{c}\text { Model } 7 \\
\text { (1) }\end{array}$ & $\begin{array}{c}\text { Model } 8 \\
\text { (2) }\end{array}$ & $\begin{array}{c}\text { Model } 9 \\
\text { (3) }\end{array}$ & $\begin{array}{l}\text { Model } 10 \\
\text { (4) }\end{array}$ & $\begin{array}{c}\text { Model } 11 \\
\text { (5) }\end{array}$ \\
\hline Age & $\begin{array}{c}0.11 \\
(1.81)\end{array}$ & $\begin{array}{c}1.65 \\
(1.39)\end{array}$ & & & \\
\hline Gender & $\begin{array}{l}-8.45 \\
(8.70)\end{array}$ & & $\begin{array}{l}-3.33 \\
(6.35)\end{array}$ & & \\
\hline Money & $\begin{array}{c}0.02 \\
(0.01)\end{array}$ & & & $\begin{array}{c}0.02 \\
(0.01)\end{array}$ & \\
\hline Period & $\begin{array}{c}0.11 \\
(0.10)\end{array}$ & & & & $\begin{array}{c}0.11 \\
(0.10)\end{array}$ \\
\hline Least successful, decreasing & $\begin{array}{c}20.04 \\
(59.90)\end{array}$ & $\begin{array}{c}62.41 \\
(48.68)\end{array}$ & $\begin{array}{l}-6.00 \\
(6.94)\end{array}$ & $\begin{array}{l}13.26 \\
(8.70)\end{array}$ & $\begin{array}{c}9.01 \\
(8.98)\end{array}$ \\
\hline Least successful,increasing & $\begin{array}{l}17.05 \\
(58.07)\end{array}$ & $\begin{array}{l}44.05 \\
(39.42)\end{array}$ & $\begin{array}{c}8.94 \\
(7.86)\end{array}$ & $\begin{array}{c}17.77^{* *} \\
(6.95)\end{array}$ & $\begin{array}{c}15.78^{* *} \\
(6.86)\end{array}$ \\
\hline Most successful, stable & $\begin{array}{c}74.02 \\
(53.88)\end{array}$ & $\begin{array}{c}112.97^{* * *} \\
(42.44)\end{array}$ & $\begin{array}{c}15.24 \\
(11.97)\end{array}$ & $\begin{array}{c}34.95^{* * *} \\
(10.59)\end{array}$ & $\begin{array}{l}19.24^{*} \\
(9.87)\end{array}$ \\
\hline Most successful, decreasing & $\begin{array}{l}-14.06 \\
(44.16)\end{array}$ & $\begin{array}{c}6.52 \\
(38.68)\end{array}$ & $\begin{array}{l}11.74 \\
(7.46)\end{array}$ & $\begin{array}{l}13.11 \\
(8.52)\end{array}$ & $\begin{array}{l}10.27 \\
(7.79)\end{array}$ \\
\hline Most successful,increasing & $\begin{array}{c}33.76 \\
(71.61)\end{array}$ & $\begin{array}{c}78.77 \\
(75.25)\end{array}$ & $\begin{array}{l}15.02^{*} \\
(8.66)\end{array}$ & $\begin{array}{c}34.37^{* * *} \\
(10.65)\end{array}$ & $\begin{array}{c}24.17^{* * * *} \\
(8.38)\end{array}$ \\
\hline Age:Least successful, decreasing & $\begin{array}{l}-1.33 \\
(2.82)\end{array}$ & $\begin{array}{l}-2.25 \\
(2.26)\end{array}$ & & & \\
\hline Age:Least successful, increasing & $\begin{array}{c}-0.003 \\
(2.66)\end{array}$ & $\begin{array}{l}-1.37 \\
(1.87)\end{array}$ & & & \\
\hline Age:Most successful, stable & $\begin{array}{l}-2.48 \\
(2.45)\end{array}$ & $\begin{array}{c}-3.98^{* *} \\
(2.02)\end{array}$ & & & \\
\hline Age:Most successful, decreasing & $\begin{array}{c}1.61 \\
(2.23)\end{array}$ & $\begin{array}{c}0.22 \\
(1.89)\end{array}$ & & & \\
\hline Age:Most successful, increasing & $\begin{array}{l}-0.62 \\
(3.64)\end{array}$ & $\begin{array}{l}-2.27 \\
(3.25)\end{array}$ & & & \\
\hline Gender:Least successful, decreasing & $\begin{array}{c}31.45^{* * *} \\
(11.12)\end{array}$ & & $\begin{array}{c}24.03^{* * *} \\
(7.90)\end{array}$ & & \\
\hline Gender:Least successful, increasing & $\begin{array}{c}9.61 \\
(14.93)\end{array}$ & & $\begin{array}{c}3.50 \\
(10.17)\end{array}$ & & \\
\hline Gender:Most successful, stable & $\begin{array}{l}12.33 \\
(11.85)\end{array}$ & & $\begin{array}{l}11.95 \\
(9.05)\end{array}$ & & \\
\hline Gender:Most successful, decreasing & $\begin{array}{l}-0.47 \\
(9.89)\end{array}$ & & $\begin{array}{l}-7.93 \\
(8.15)\end{array}$ & & \\
\hline Gender:Most successful, increasing & $\begin{array}{l}22.38 \\
(15.31)\end{array}$ & & $\begin{array}{c}17.68 \\
(14.33)\end{array}$ & & \\
\hline Money:Least successful, decreasing & $\begin{array}{c}-0.002 \\
(0.02)\end{array}$ & & & $\begin{array}{l}-0.01 \\
(0.01)\end{array}$ & \\
\hline Money:Least successful, increasing & $\begin{array}{l}-0.01 \\
(0.01)\end{array}$ & & & $\begin{array}{l}-0.01 \\
(0.01)\end{array}$ & \\
\hline Money:Most successful, stable & $\begin{array}{l}-0.01 \\
(0.02)\end{array}$ & & & $\begin{array}{l}-0.02 \\
(0.02)\end{array}$ & \\
\hline Money:Most successful, decreasing & $\begin{array}{l}-0.02 \\
(0.01)\end{array}$ & & & $\begin{array}{l}-0.01 \\
(0.02)\end{array}$ & \\
\hline Money:Most successful, increasing & $\begin{array}{l}-0.01 \\
(0.02)\end{array}$ & & & $\begin{array}{l}-0.01 \\
(0.02)\end{array}$ & \\
\hline Period:Least successful, decreasing & $\begin{array}{c}0.01 \\
(0.13)\end{array}$ & & & & $\begin{array}{c}0.01 \\
(0.13)\end{array}$ \\
\hline Period:Least successful, increasing & $\begin{array}{l}-0.21 \\
(0.20)\end{array}$ & & & & $\begin{array}{l}-0.21 \\
(0.19)\end{array}$ \\
\hline Period:Most successful, stable & $\begin{array}{c}0.15 \\
(0.23)\end{array}$ & & & & $\begin{array}{c}0.15 \\
(0.23)\end{array}$ \\
\hline Period:Most successful, decreasing & $\begin{array}{l}-0.11 \\
(0.18)\end{array}$ & & & & $\begin{array}{l}-0.11 \\
(0.18)\end{array}$ \\
\hline Period:Most successful, increasing & $\begin{array}{c}0.07 \\
(0.16)\end{array}$ & & & & $\begin{array}{c}0.07 \\
(0.16)\end{array}$ \\
\hline Constant & $\begin{array}{c}4.55 \\
(34.01)\end{array}$ & $\begin{array}{l}-23.15 \\
(28.92)\end{array}$ & $\begin{array}{c}17.96^{* * *} \\
(5.65)\end{array}$ & $\begin{array}{c}4.72 \\
(4.66)\end{array}$ & $\begin{array}{c}13.42^{* *} \\
(6.30)\end{array}$ \\
\hline
\end{tabular}

Note:Standard errors clustered at group level, 1st period omitted.

${ }^{*} \mathrm{p}<0.1 ;{ }^{* *} \mathrm{p}<0.05 ;{ }^{* * *} \mathrm{p}<0.01$ 
Table 8: Interaction models, bootstrapped clustering

\begin{tabular}{|c|c|c|c|c|c|}
\hline & \multicolumn{5}{|c|}{ DV: DiffAllocation } \\
\hline & Model 7 & Model 8 & Model 9 & Model 10 & Model 11 \\
\hline Age & $\begin{array}{l}-0.22 \\
(0.40)\end{array}$ & $\begin{array}{c}0.25 \\
(0.28)\end{array}$ & & & \\
\hline Gender & $\begin{array}{l}-3.36 \\
(2.20)\end{array}$ & & $\begin{array}{l}-1.68 \\
(1.74)\end{array}$ & & \\
\hline Money & $\begin{array}{c}0.01 \\
(0.003)\end{array}$ & & & $\begin{array}{c}0.003 \\
(0.003)\end{array}$ & \\
\hline Period & $\begin{array}{c}0.01 \\
(0.02)\end{array}$ & & & & $\begin{array}{c}0.01 \\
(0.02)\end{array}$ \\
\hline Least successful, decreasing & $\begin{array}{c}-0.72 \\
(13.92)\end{array}$ & $\begin{array}{l}10.99 \\
(9.31)\end{array}$ & $\begin{array}{l}-1.60 \\
(1.72)\end{array}$ & $\begin{array}{c}2.28 \\
(1.92)\end{array}$ & $\begin{array}{c}1.76 \\
(2.17)\end{array}$ \\
\hline Least successful,increasing & $\begin{array}{c}2.97 \\
(11.88)\end{array}$ & $\begin{array}{l}11.65 \\
(8.11)\end{array}$ & $\begin{array}{c}2.00 \\
(1.48)\end{array}$ & $\begin{array}{l}3.04^{* *} \\
(1.35)\end{array}$ & $\begin{array}{l}3.27^{* *} \\
(1.52)\end{array}$ \\
\hline Most successful, stable & $\begin{array}{c}10.11 \\
(10.86)\end{array}$ & $\begin{array}{c}21.20^{* *} \\
(8.54)\end{array}$ & $\begin{array}{c}2.53 \\
(2.30)\end{array}$ & $\begin{array}{l}7.35^{* * *} \\
(1.75)\end{array}$ & $\begin{array}{l}4.15^{* *} \\
(1.89)\end{array}$ \\
\hline Most successful, decreasing & $\begin{array}{l}-5.81 \\
(9.64)\end{array}$ & $\begin{array}{c}1.42 \\
(7.93)\end{array}$ & $\begin{array}{c}2.19 \\
(1.57)\end{array}$ & $\begin{array}{l}2.87^{*} \\
(1.60)\end{array}$ & $\begin{array}{l}2.81^{*} \\
(1.69)\end{array}$ \\
\hline Most successful,increasing & $\begin{array}{c}7.05 \\
(13.75)\end{array}$ & $\begin{array}{c}18.75 \\
(13.53)\end{array}$ & $\begin{array}{l}2.94^{*} \\
(1.78)\end{array}$ & $\begin{array}{l}7.20^{* * *} \\
(1.81)\end{array}$ & $\begin{array}{c}5.19^{* * *} \\
(1.64)\end{array}$ \\
\hline Age:Least successful, decreasing & $\begin{array}{l}-0.04 \\
(0.64)\end{array}$ & $\begin{array}{l}-0.40 \\
(0.44)\end{array}$ & & & \\
\hline Age:Least successful, increasing & $\begin{array}{c}0.03 \\
(0.56)\end{array}$ & $\begin{array}{l}-0.40 \\
(0.38)\end{array}$ & & & \\
\hline Age:Most successful, stable & $\begin{array}{c}-0.24 \\
(0.52)\end{array}$ & $\begin{array}{c}-0.74^{*} \\
(0.41)\end{array}$ & & & \\
\hline Age:Most successful, decreasing & $\begin{array}{c}0.48 \\
(0.49)\end{array}$ & $\begin{array}{c}0.05 \\
(0.39)\end{array}$ & & & \\
\hline Age:Most successful, increasing & $\begin{array}{c}-0.09 \\
(0.71)\end{array}$ & $\begin{array}{l}-0.58 \\
(0.59)\end{array}$ & & & \\
\hline Gender:Least successful, decreasing & $\begin{array}{c}7.40^{* * *} \\
(2.63)\end{array}$ & & $\begin{array}{l}5.21^{* *} \\
(2.05)\end{array}$ & & \\
\hline Gender:Least successful, increasing & $\begin{array}{c}2.58 \\
(3.46)\end{array}$ & & $\begin{array}{c}0.59 \\
(2.52)\end{array}$ & & \\
\hline Gender:Most successful, stable & $\begin{array}{l}4.02^{*} \\
(2.44)\end{array}$ & & $\begin{array}{c}3.22 \\
(2.05)\end{array}$ & & \\
\hline Gender:Most successful, decreasing & $\begin{array}{c}1.39 \\
(2.48)\end{array}$ & & $\begin{array}{l}-0.66 \\
(2.16)\end{array}$ & & \\
\hline Gender:Most successful, increasing & $\begin{array}{l}5.48^{*} \\
(3.08)\end{array}$ & & $\begin{array}{c}3.94 \\
(3.06)\end{array}$ & & \\
\hline Money:Least successful, decreasing & $\begin{array}{c}-0.002 \\
(0.004)\end{array}$ & & & $\begin{array}{l}-0.001 \\
(0.003)\end{array}$ & \\
\hline Money:Least successful, increasing & $\begin{array}{c}-0.003 \\
(0.004)\end{array}$ & & & $\begin{array}{l}-0.001 \\
(0.003)\end{array}$ & \\
\hline Money:Most successful, stable & $\begin{array}{l}-0.01 \\
(0.005)\end{array}$ & & & $\begin{array}{l}-0.004 \\
(0.004)\end{array}$ & \\
\hline Money:Most successful, decreasing & $\begin{array}{l}-0.005 \\
(0.004)\end{array}$ & & & $\begin{array}{l}-0.001 \\
(0.003)\end{array}$ & \\
\hline Money:Most successful, increasing & $\begin{array}{l}-0.005 \\
(0.004)\end{array}$ & & & $\begin{array}{l}-0.003 \\
(0.004)\end{array}$ & \\
\hline Period:Least successful, decreasing & $\begin{array}{c}-0.004 \\
(0.03)\end{array}$ & & & & $\begin{array}{c}-0.004 \\
(0.03)\end{array}$ \\
\hline Period:Least successful, increasing & $\begin{array}{l}-0.04 \\
(0.04)\end{array}$ & & & & $\begin{array}{l}-0.04 \\
(0.04)\end{array}$ \\
\hline Period:Most successful, stable & $\begin{array}{c}0.02 \\
(0.04)\end{array}$ & & & & $\begin{array}{c}0.02 \\
(0.04)\end{array}$ \\
\hline Period:Most successful, decreasing & $\begin{array}{l}-0.04 \\
(0.04)\end{array}$ & & & & $\begin{array}{l}-0.04 \\
(0.04)\end{array}$ \\
\hline Period:Most successful, increasing & $\begin{array}{c}0.01 \\
(0.03)\end{array}$ & & & & $\begin{array}{c}0.01 \\
(0.03)\end{array}$ \\
\hline Constant & $\begin{array}{c}8.83 \\
(7.53)\end{array}$ & $\begin{array}{l}-0.59 \\
(5.82)\end{array}$ & $\begin{array}{c}6.40^{* * *} \\
(1.21)\end{array}$ & $\begin{array}{c}3.50^{* * *} \\
(1.00)\end{array}$ & $\begin{array}{l}5.12^{* * *} \\
(1.37)\end{array}$ \\
\hline
\end{tabular}




\subsection{Estimations using asymptotic cluster-robust standard}

\section{errors}

Table 9: parametric cluster-robust standard errors

\begin{tabular}{|c|c|c|c|c|c|c|c|c|c|c|c|}
\hline & \multicolumn{11}{|c|}{ DV: DiffAllocation } \\
\hline & Model 1 & Model 2 & Model 3 & Model 4 & Model 5 & Model 6 & Model 7 & Model 8 & Model 9 & Model 10 & Model 11 \\
\hline Age & $\begin{array}{l}-0.22 \\
(0.17)\end{array}$ & $\begin{array}{l}-0.09 \\
(0.09)\end{array}$ & & $\begin{array}{l}0.25^{*} \\
(0.14)\end{array}$ & $\begin{array}{c}0.0004 \\
(0.11)\end{array}$ & & & & & & \\
\hline Gender & $\begin{array}{c}-3.36^{* *} \\
(1.44)\end{array}$ & $\begin{array}{c}0.28 \\
(0.70)\end{array}$ & & & & $\begin{array}{l}-1.68 \\
(1.48)\end{array}$ & $\begin{array}{c}0.39 \\
(0.70)\end{array}$ & & & & \\
\hline Money & $\begin{array}{l}0.01^{* * *} \\
(0.002)\end{array}$ & $\begin{array}{c}0.002^{* * *} \\
(0.001)\end{array}$ & & & & & & $\begin{array}{c}0.003^{* * *} \\
(0.001)\end{array}$ & $\begin{array}{c}0.002^{* *} \\
(0.001)\end{array}$ & & \\
\hline Period & $\begin{array}{c}0.01 \\
(0.02)\end{array}$ & $\begin{array}{l}0.001 \\
(0.01)\end{array}$ & & & & & & & & $\begin{array}{c}0.01 \\
(0.02)\end{array}$ & $\begin{array}{l}0.001 \\
(0.01)\end{array}$ \\
\hline Least successful, decreasing & $\begin{array}{l}-0.72 \\
(3.71)\end{array}$ & $\begin{array}{c}1.41 \\
(1.38)\end{array}$ & $\begin{array}{c}1.66 \\
(1.51)\end{array}$ & $\begin{array}{c}10.99^{* * *} \\
(3.25)\end{array}$ & $\begin{array}{c}1.66 \\
(1.49)\end{array}$ & $\begin{array}{l}-1.60 \\
(1.44)\end{array}$ & $\begin{array}{c}1.64 \\
(1.50)\end{array}$ & $\begin{array}{c}2.28 \\
(1.48)\end{array}$ & $\begin{array}{c}1.51 \\
(1.40)\end{array}$ & $\begin{array}{c}1.76 \\
(1.95)\end{array}$ & $\begin{array}{c}1.66 \\
(1.51)\end{array}$ \\
\hline Least successful,increasing & $\begin{array}{c}2.97 \\
(6.55)\end{array}$ & $\begin{array}{l}2.20^{* *} \\
(0.86)\end{array}$ & $\begin{array}{l}2.31^{* *} \\
(1.05)\end{array}$ & $\begin{array}{l}11.65^{*} \\
(6.38)\end{array}$ & $\begin{array}{l}2.31^{* *} \\
(0.98)\end{array}$ & $\begin{array}{c}2.00 \\
(1.33)\end{array}$ & $\begin{array}{l}2.30^{* *} \\
(1.04)\end{array}$ & $\begin{array}{l}3.04^{* * * *} \\
(0.84)\end{array}$ & $\begin{array}{c}2.36^{* * *} \\
(0.88)\end{array}$ & $\begin{array}{l}3.27^{* *} \\
(1.35)\end{array}$ & $\begin{array}{l}2.31^{* *} \\
(1.05)\end{array}$ \\
\hline Most successful, stable & $\begin{array}{l}10.11^{*} \\
(5.43)\end{array}$ & $\begin{array}{c}4.48^{* * *} \\
(1.53)\end{array}$ & $\begin{array}{c}4.53^{* * *} \\
(1.67)\end{array}$ & $\begin{array}{c}21.20^{* * *} \\
(4.58)\end{array}$ & $\begin{array}{c}4.53^{* * *} \\
(1.63)\end{array}$ & $\begin{array}{c}2.53 \\
(1.87)\end{array}$ & $\begin{array}{c}4.51^{* * *} \\
(1.66)\end{array}$ & $\begin{array}{c}7.35^{* * *} \\
(1.32)\end{array}$ & $\begin{array}{l}4.64^{* * *} \\
(1.57)\end{array}$ & $\begin{array}{l}4.15^{* *} \\
(1.76)\end{array}$ & $\begin{array}{c}4.53^{* * *} \\
(1.67)\end{array}$ \\
\hline Most successful, decreasing & $\begin{array}{l}-5.81 \\
(3.89)\end{array}$ & $\begin{array}{l}1.90^{* *} \\
(0.94)\end{array}$ & $\begin{array}{l}1.96^{*} \\
(1.08)\end{array}$ & $\begin{array}{c}1.42 \\
(2.89)\end{array}$ & $\begin{array}{l}1.96^{* *} \\
(1.00)\end{array}$ & $\begin{array}{l}2.19^{*} \\
(1.32)\end{array}$ & $\begin{array}{l}1.99^{*} \\
(1.06)\end{array}$ & $\begin{array}{c}2.87^{* * *} \\
(1.00)\end{array}$ & $\begin{array}{l}2.05^{* *} \\
(0.93)\end{array}$ & $\begin{array}{l}2.81^{*} \\
(1.50)\end{array}$ & $\begin{array}{l}1.96^{*} \\
(1.08)\end{array}$ \\
\hline Most successful,increasing & $\begin{array}{l}7.05 \\
(8.08)\end{array}$ & $\begin{array}{c}5.26^{* * *} \\
(1.23)\end{array}$ & $\begin{array}{l}5.33^{* * *} \\
(1.29)\end{array}$ & $\begin{array}{l}18.75^{*} \\
(10.58)\end{array}$ & $\begin{array}{c}5.33^{* * *} \\
(1.22)\end{array}$ & $\begin{array}{l}2.94^{*} \\
(1.58)\end{array}$ & $\begin{array}{l}5.33^{* * *} \\
(1.28)\end{array}$ & $\begin{array}{l}7.20^{* * * *} \\
(1.04)\end{array}$ & $\begin{array}{l}5.39^{* * * *} \\
(1.22)\end{array}$ & $\begin{array}{l}5.19^{* * * *} \\
(1.45)\end{array}$ & $\begin{array}{l}5.33^{* * *} \\
(1.29)\end{array}$ \\
\hline Age:Least successful, decreasing & $\begin{array}{l}-0.04 \\
(0.18)\end{array}$ & & & $\begin{array}{c}-0.40^{* * *} \\
(0.14)\end{array}$ & & & & & & & \\
\hline Age:Least successful, increasing & $\begin{array}{c}0.03 \\
(0.32)\end{array}$ & & & $\begin{array}{l}-0.40 \\
(0.30)\end{array}$ & & & & & & & \\
\hline Age:Most successful, stable & $\begin{array}{l}-0.24 \\
(0.25)\end{array}$ & & & $\begin{array}{c}-0.74^{* * *} \\
(0.22)\end{array}$ & & & & & & & \\
\hline Age:Most successful, decreasing & $\begin{array}{c}0.48^{* * *} \\
(0.18)\end{array}$ & & & $\begin{array}{c}0.05 \\
(0.15)\end{array}$ & & & & & & & \\
\hline Age:Most successful, increasing & $\begin{array}{l}-0.09 \\
(0.40)\end{array}$ & & & $\begin{array}{l}-0.58 \\
(0.45)\end{array}$ & & & & & & & \\
\hline Gender:Least successful, decreasing & $\begin{array}{c}7.40^{* * *} \\
(1.61)\end{array}$ & & & & & $\begin{array}{c}5.21^{* * *} \\
(1.69)\end{array}$ & & & & & \\
\hline Gender:Least successful, increasing & $\begin{array}{c}2.58 \\
(2.19)\end{array}$ & & & & & $\begin{array}{c}0.59 \\
(2.22)\end{array}$ & & & & & \\
\hline Gender:Most successful, stable & $\begin{array}{l}4.02^{* *} \\
(1.67)\end{array}$ & & & & & $\begin{array}{l}3.22^{* *} \\
(1.59)\end{array}$ & & & & & \\
\hline Gender:Most successful, decreasing & $\begin{array}{c}1.39 \\
(1.68)\end{array}$ & & & & & $\begin{array}{l}-0.66 \\
(1.83)\end{array}$ & & & & & \\
\hline Gender:Most successful, increasing & $\begin{array}{l}5.48^{* *} \\
(2.25)\end{array}$ & & & & & $\begin{array}{c}3.94 \\
(2.77)\end{array}$ & & & & & \\
\hline Money:Least successful, decreasing & $\begin{array}{l}-0.002 \\
(0.002)\end{array}$ & & & & & & & $\begin{array}{l}-0.001 \\
(0.002)\end{array}$ & & & \\
\hline Money:Least successful, increasing & $\begin{array}{c}-0.003^{*} \\
(0.002)\end{array}$ & & & & & & & $\begin{array}{l}-0.001 \\
(0.001)\end{array}$ & & & \\
\hline Money:Most successful, stable & $\begin{array}{l}-0.01^{*} \\
(0.003)\end{array}$ & & & & & & & $\begin{array}{l}-0.004 \\
(0.003)\end{array}$ & & & \\
\hline Money:Most successful, decreasing & $\begin{array}{c}-0.005^{* * *} \\
(0.002)\end{array}$ & & & & & & & $\begin{array}{l}-0.001 \\
(0.002)\end{array}$ & & & \\
\hline Money:Most successful, increasing & $\begin{array}{c}-0.005^{* *} \\
(0.002)\end{array}$ & & & & & & & $\begin{array}{c}-0.003^{*} \\
(0.002)\end{array}$ & & & \\
\hline Period:Least successful, decreasing & $\begin{array}{c}-0.004 \\
(0.03)\end{array}$ & & & & & & & & & $\begin{array}{c}-0.004 \\
(0.03)\end{array}$ & \\
\hline Period:Least successful, increasing & $\begin{array}{l}-0.04 \\
(0.04)\end{array}$ & & & & & & & & & $\begin{array}{l}-0.04 \\
(0.04)\end{array}$ & \\
\hline Period:Most successful, stable & $\begin{array}{c}0.02 \\
(0.04)\end{array}$ & & & & & & & & & $\begin{array}{c}0.02 \\
(0.04)\end{array}$ & \\
\hline Period:Most successful, decreasing & $\begin{array}{l}-0.04 \\
(0.04)\end{array}$ & & & & & & & & & $\begin{array}{l}-0.04 \\
(0.04)\end{array}$ & \\
\hline Period:Most successful, increasing & $\begin{array}{c}0.01 \\
(0.03)\end{array}$ & & & & & & & & & $\begin{array}{c}0.01 \\
(0.03)\end{array}$ & \\
\hline Constant & $\begin{array}{c}8.83^{* * *} \\
(3.20)\end{array}$ & $\begin{array}{c}6.04^{* * *} \\
(1.76) \\
\end{array}$ & $\begin{array}{c}5.39^{* * *} \\
(0.94) \\
\end{array}$ & $\begin{array}{l}-0.59 \\
(2.57)\end{array}$ & $\begin{array}{l}5.38^{* *} \\
(2.23) \\
\end{array}$ & $\begin{array}{c}6.40^{* * *} \\
(1.02) \\
\end{array}$ & $\begin{array}{c}5.15^{* * *} \\
(0.96) \\
\end{array}$ & $\begin{array}{c}3.50^{* * * *} \\
(0.20) \\
\end{array}$ & $\begin{array}{c}4.32^{* * *} \\
(0.60) \\
\end{array}$ & $\begin{array}{c}5.12^{* * *} \\
(1.19)\end{array}$ & $\begin{array}{c}5.36^{* * *} \\
(1.01)\end{array}$ \\
\hline
\end{tabular}


Table 10: parametric cluster-robust standard errors

\begin{tabular}{|c|c|c|c|c|c|c|c|c|c|c|c|}
\hline & \multicolumn{11}{|c|}{ DV: VarAllocation } \\
\hline & Model 1 & Model 2 & Model 3 & Model 4 & Model 5 & Model 6 & Model 7 & Model 8 & Model 9 & Model 10 & Model 11 \\
\hline Age & $\begin{array}{c}0.11 \\
(0.79)\end{array}$ & $\begin{array}{l}-0.17 \\
(0.53)\end{array}$ & & $\begin{array}{l}1.65^{* *} \\
(0.65)\end{array}$ & $\begin{array}{c}0.31 \\
(0.60)\end{array}$ & & & & & & \\
\hline Gender & $\begin{array}{l}-8.45 \\
(6.00)\end{array}$ & $\begin{array}{c}4.37 \\
(3.38)\end{array}$ & & & & $\begin{array}{l}-3.33 \\
(5.82)\end{array}$ & $\begin{array}{c}4.88 \\
(3.35)\end{array}$ & & & & \\
\hline Money & $\begin{array}{l}0.02^{* *} \\
(0.01)\end{array}$ & $\begin{array}{c}0.01^{* *} \\
(0.004)\end{array}$ & & & & & & $\begin{array}{c}0.02^{* * *} \\
(0.01)\end{array}$ & $\begin{array}{c}0.01^{* *} \\
(0.004)\end{array}$ & & \\
\hline Period & $\begin{array}{c}0.11 \\
(0.09)\end{array}$ & $\begin{array}{c}0.10 \\
(0.06)\end{array}$ & & & & & & & & $\begin{array}{c}0.11 \\
(0.09)\end{array}$ & $\begin{array}{c}0.10 \\
(0.06)\end{array}$ \\
\hline Least successful, decreasing & $\begin{array}{c}20.04 \\
(15.97)\end{array}$ & $\begin{array}{c}8.01 \\
(6.05)\end{array}$ & $\begin{array}{c}9.22 \\
(6.77)\end{array}$ & $\begin{array}{c}62.41^{* * *} \\
(15.08)\end{array}$ & $\begin{array}{c}9.37 \\
(6.52)\end{array}$ & $\begin{array}{l}-6.00 \\
(5.97)\end{array}$ & $\begin{array}{c}9.03 \\
(6.61)\end{array}$ & $\begin{array}{c}13.26^{* *} \\
(6.39)\end{array}$ & $\begin{array}{c}8.32 \\
(6.21)\end{array}$ & $\begin{array}{c}9.01 \\
(8.08)\end{array}$ & $\begin{array}{c}9.22 \\
(6.77)\end{array}$ \\
\hline Least successful,increasing & $\begin{array}{c}17.05 \\
(33.02)\end{array}$ & $\begin{array}{c}10.90^{* *} \\
(4.26)\end{array}$ & $\begin{array}{l}11.04^{* *} \\
(5.45)\end{array}$ & $\begin{array}{c}44.05 \\
(28.76)\end{array}$ & $\begin{array}{c}11.58^{* *} \\
(4.91)\end{array}$ & $\begin{array}{c}8.94 \\
(6.87)\end{array}$ & $\begin{array}{c}10.85^{* *} \\
(5.30)\end{array}$ & $\begin{array}{c}17.77^{* * * *} \\
(4.93)\end{array}$ & $\begin{array}{c}11.35^{* *} \\
(4.41)\end{array}$ & $\begin{array}{c}15.78^{* *} \\
(6.17)\end{array}$ & $\begin{array}{c}11.04^{* *} \\
(5.45)\end{array}$ \\
\hline Most successful, stable & $\begin{array}{c}74.02^{* * *} \\
(25.95)\end{array}$ & $\begin{array}{c}22.97^{* * *} \\
(8.04)\end{array}$ & $\begin{array}{c}22.74^{* * *} \\
(8.70)\end{array}$ & $\begin{array}{c}112.97^{* * * *} \\
(22.29)\end{array}$ & $\begin{array}{c}23.31^{* * *} \\
(8.51)\end{array}$ & $\begin{array}{l}15.24 \\
(9.94)\end{array}$ & $\begin{array}{c}22.55^{* * * *} \\
(8.54)\end{array}$ & $\begin{array}{c}34.95^{* * * *} \\
(8.29)\end{array}$ & $\begin{array}{c}23.42^{* * * *} \\
(8.24)\end{array}$ & $\begin{array}{c}19.24^{* *} \\
(9.16)\end{array}$ & $\begin{array}{c}22.74^{* * * *} \\
(8.70)\end{array}$ \\
\hline Most successful, decreasing & $\begin{array}{l}-14.06 \\
(18.08)\end{array}$ & $\begin{array}{l}8.31^{*} \\
(4.91)\end{array}$ & $\begin{array}{c}7.80 \\
(5.51)\end{array}$ & $\begin{array}{c}6.52 \\
(14.35)\end{array}$ & $\begin{array}{l}8.43^{*} \\
(4.96)\end{array}$ & $\begin{array}{l}11.74^{*} \\
(6.74)\end{array}$ & $\begin{array}{c}8.15 \\
(5.46)\end{array}$ & $\begin{array}{c}13.11^{* *} \\
(5.61)\end{array}$ & $\begin{array}{l}8.31^{*} \\
(4.74)\end{array}$ & $\begin{array}{l}10.27 \\
(6.97)\end{array}$ & $\begin{array}{c}7.80 \\
(5.51)\end{array}$ \\
\hline Most successful,increasing & $\begin{array}{c}33.76 \\
(42.87)\end{array}$ & $\begin{array}{c}25.85^{* * *} \\
(6.60)\end{array}$ & $\begin{array}{c}25.79^{* * * *} \\
(7.10)\end{array}$ & $\begin{array}{c}78.77 \\
(58.66)\end{array}$ & $\begin{array}{c}26.24^{* * *} \\
(6.50)\end{array}$ & $\begin{array}{l}15.02^{*} \\
(7.83)\end{array}$ & $\begin{array}{c}25.73^{* * *} \\
(6.97)\end{array}$ & $\begin{array}{c}34.37^{* * *} \\
(6.90)\end{array}$ & $\begin{array}{c}26.13^{* * *} \\
(6.78)\end{array}$ & $\begin{array}{c}24.17^{* * *} \\
(7.41)\end{array}$ & $\begin{array}{c}25.79^{* * *} \\
(7.10)\end{array}$ \\
\hline Age:Least successful, decreasing & $\begin{array}{l}-1.33 \\
(0.84)\end{array}$ & & & $\begin{array}{c}-2.25^{* * * *} \\
(0.69)\end{array}$ & & & & & & & \\
\hline Age:Least successful, increasing & $\begin{array}{c}-0.003 \\
(1.58)\end{array}$ & & & $\begin{array}{l}-1.37 \\
(1.40)\end{array}$ & & & & & & & \\
\hline Age:Most successful, stable & $\begin{array}{c}-2.48^{* *} \\
(1.14)\end{array}$ & & & $\begin{array}{c}-3.98^{* * *} \\
(1.06)\end{array}$ & & & & & & & \\
\hline Age:Most successful, decreasing & $\begin{array}{l}1.61^{*} \\
(0.86)\end{array}$ & & & $\begin{array}{c}0.22 \\
(0.75)\end{array}$ & & & & & & & \\
\hline Age:Most successful, increasing & $\begin{array}{l}-0.62 \\
(2.09)\end{array}$ & & & $\begin{array}{l}-2.27 \\
(2.49)\end{array}$ & & & & & & & \\
\hline Gender:Least successful, decreasing & $\begin{array}{c}31.45^{* * *} \\
(7.28)\end{array}$ & & & & & $\begin{array}{c}24.03^{* * *} \\
(6.70)\end{array}$ & & & & & \\
\hline Gender:Least successful, increasing & $\begin{array}{c}9.61 \\
(9.39)\end{array}$ & & & & & $\begin{array}{c}3.50 \\
(9.43)\end{array}$ & & & & & \\
\hline Gender:Most successful, stable & $\begin{array}{l}12.33 \\
(8.16)\end{array}$ & & & & & $\begin{array}{l}11.95^{*} \\
(7.00)\end{array}$ & & & & & \\
\hline Gender:Most successful, decreasing & $\begin{array}{l}-0.47 \\
(6.76)\end{array}$ & & & & & $\begin{array}{l}-7.93 \\
(7.29)\end{array}$ & & & & & \\
\hline Gender:Most successful, increasing & $\begin{array}{c}22.38^{*} \\
(11.85)\end{array}$ & & & & & $\begin{array}{c}17.68 \\
(12.84)\end{array}$ & & & & & \\
\hline Money:Least successful, decreasing & $\begin{array}{c}-0.002 \\
(0.01)\end{array}$ & & & & & & & $\begin{array}{l}-0.01 \\
(0.01)\end{array}$ & & & \\
\hline Money:Least successful, increasing & $\begin{array}{l}-0.01 \\
(0.01)\end{array}$ & & & & & & & $\begin{array}{l}-0.01 \\
(0.01)\end{array}$ & & & \\
\hline Money:Most successful, stable & $\begin{array}{l}-0.01 \\
(0.02)\end{array}$ & & & & & & & $\begin{array}{l}-0.02 \\
(0.02)\end{array}$ & & & \\
\hline Money:Most successful, decreasing & $\begin{array}{c}-0.02^{* *} \\
(0.01)\end{array}$ & & & & & & & $\begin{array}{l}-0.01 \\
(0.01)\end{array}$ & & & \\
\hline Money:Most successful, increasing & $\begin{array}{l}-0.01 \\
(0.01)\end{array}$ & & & & & & & $\begin{array}{l}-0.01 \\
(0.01)\end{array}$ & & & \\
\hline Period:Least successful, decreasing & $\begin{array}{c}0.01 \\
(0.12)\end{array}$ & & & & & & & & & $\begin{array}{c}0.01 \\
(0.12)\end{array}$ & \\
\hline Period:Least successful, increasing & $\begin{array}{l}-0.21 \\
(0.18)\end{array}$ & & & & & & & & & $\begin{array}{l}-0.21 \\
(0.18)\end{array}$ & \\
\hline Period:Most successful, stable & $\begin{array}{c}0.15 \\
(0.22)\end{array}$ & & & & & & & & & $\begin{array}{c}0.15 \\
(0.22)\end{array}$ & \\
\hline Period:Most successful, decreasing & $\begin{array}{l}-0.11 \\
(0.17)\end{array}$ & & & & & & & & & $\begin{array}{l}-0.11 \\
(0.17)\end{array}$ & \\
\hline Period:Most successful, increasing & $\begin{array}{c}0.07 \\
(0.15)\end{array}$ & & & & & & & & & $\begin{array}{c}0.07 \\
(0.15)\end{array}$ & \\
\hline Constant & $\begin{array}{c}4.55 \\
(13.99) \\
\end{array}$ & $\begin{array}{c}8.12 \\
(10.54) \\
\end{array}$ & $\begin{array}{c}15.97^{* * *} \\
(4.60)\end{array}$ & $\begin{array}{c}-23.15^{*} \\
(11.89) \\
\end{array}$ & $\begin{array}{c}8.69 \\
(12.43) \\
\end{array}$ & $\begin{array}{c}17.96^{* * *} \\
(4.99) \\
\end{array}$ & $\begin{array}{c}13.04^{* * *} \\
(4.74) \\
\end{array}$ & $\begin{array}{l}4.72^{* * *} \\
(0.90) \\
\end{array}$ & $\begin{array}{c}9.32^{* * *} \\
(2.96) \\
\end{array}$ & $\begin{array}{c}13.42^{* *} \\
(5.50)\end{array}$ & $\begin{array}{c}13.74^{* * *} \\
(4.88) \\
\end{array}$ \\
\hline
\end{tabular}




\subsection{Imitation: Models}

Table 11: Imitation: Difference of Allocation by treatment.

\begin{tabular}{|c|c|c|c|c|c|c|}
\hline & \multicolumn{6}{|c|}{ DV: Difference of Allocation (simple) } \\
\hline & Least successful, stable & Least successful, decreasing & Least successful, increasing & Most successful, stable & Most successful, decreasing & Most successful, stable \\
\hline Age & $\begin{array}{c}0.45 \\
(0.27\end{array}$ & $\begin{array}{l}-0.17 \\
\end{array}$ & $\begin{array}{c}0.50^{* * *} \\
(0.15)\end{array}$ & $\begin{array}{c}0.05 \\
0.12)\end{array}$ & $\begin{array}{c}0.19 \\
(0.255\end{array}$ & -0.13 \\
\hline Gender & -0.04 & $2.46^{*}$ & 0.39 & -2.38 & 0.13 & 0.31 \\
\hline & $(1.55)$ & $(1.25)$ & $(1.54)$ & $(1.83)$ & $(0.81)$ & $(1.42)$ \\
\hline Money & -0.001 & 0.004 & 0.001 & 0.001 & $-0.004^{* * *}$ & -0.001 \\
\hline & $(0.002)$ & $(0.002)$ & $(0.001)$ & $(0.003)$ & $(0.001)$ & $(0.003)$ \\
\hline Period & $\begin{array}{c}-0.02^{*} \\
(0.01)\end{array}$ & $\begin{array}{c}-0.003 \\
(0.03)\end{array}$ & $\begin{array}{c}0.02 \\
(0.04)\end{array}$ & $\begin{array}{l}-0.08^{*} \\
(0.04)\end{array}$ & $\begin{array}{c}-0.08^{* *+} \\
(0.03)\end{array}$ & $\begin{array}{c}0.01 \\
(0.03)\end{array}$ \\
\hline Difference of Allocation (t-1) & $\begin{array}{l}-0.01 \\
(0.04)\end{array}$ & $\begin{array}{l}0.11^{* *} \\
(0.04)\end{array}$ & $\begin{array}{l}0.05 \\
(0.05)\end{array}$ & $\begin{array}{c}-0.12^{2 * * *} \\
(0.04)\end{array}$ & $\begin{array}{c}-0.09^{* *} \\
(0.04)\end{array}$ & $\begin{array}{c}-0.13^{* * * *} \\
(0.03)\end{array}$ \\
\hline Constant & $\begin{array}{c}-10.06^{* *} \\
(5.03)\end{array}$ & $\begin{array}{l}0.47 \\
(2.38)\end{array}$ & $\begin{array}{c}-11.83^{* * *} \\
(3.56)\end{array}$ & $\begin{array}{c}0.09 \\
(3.32)\end{array}$ & $\begin{array}{c}0.09 \\
(5.26)\end{array}$ & $\begin{array}{l}5.01 \\
(5.08)\end{array}$ \\
\hline
\end{tabular}

\subsection{Main Hypothesis: Additional Evidence}

Our main analysis shows that average risk-seeking is larger in the Most Successful relative to the Least Successful treatment. In principle, such a pattern could also result if the Least Successful treatment were to induce a decline in risk-seeking over time, while risk-seeking stays constant in the Most Successful treatment. In such a case, the treatment effect would be driven by what is going on in the Least Successful treatment. Thus, to use metaphorical language, if worst performance information would be like a "poison" that decreases risk-seeking, it would be a challenge to conclude that top performance information were a fitting "medicine" that increases risk-seeking (Lonati et al., 2018).

To assess whether higher risk-seeking in the Most Successful treatment is a consequence of increased risk-seeking in that treatment, rather than decreased risk-seeking in the Least Successful treatment, we conduct additional regression analyses, summarized in Table12. The estimated model allows to compare individual risk-seeking in the first period to the average risk-seeking of a given individual in all subsequent periods ${ }^{14}$

\footnotetext{
${ }^{14}$ Including some or all our demographic controls does not affect the estimated coefficients. Further, a fine-grained analysis shows that this pattern is mainly driven by the Increasing and the
} 
Three findings are noteworthy. First, there is no effect of the dummy variable "Most Successful" on risk-seeking in the first period. This is as expected, because subjects have been randomly assigned to treatments, and make their first investment decision without observing any social information. Second, the positive and significant coefficient on "Time", which is a dummy variable for periods 2-45, indicates that average individual risk-seeking increases once subjects are exposed to social information associating risk-seeking with least success. This makes it unlikely that our main treatment effect is driven by decreasing risk-seeking in the Least Successful treatment. Likewise, visual inspection of average risk-seeking over time for all groups does not support that risk-seeking has decreased over time in the Least Successful treatment (see Figure 90). In addition, we estimate an alternative specification in Tables 13 and 14, where we compare risk-seeking of the first and the last period. Again, we find no evidence that risk-seeking decreases in the Least Successful treatment over time. Third, the significant coefficient on the interaction term shows that risk-seeking increases much more in the Most Successful treatment, which again is consistent with our main hypothesis.

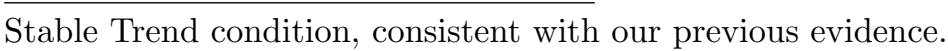




\begin{tabular}{lcc}
\hline \hline & & \\
& & \\
& VarAllocation & DiffAllocation \\
\hline Time & $4.874^{* *}$ & $1.132^{* *}$ \\
& $(2.318)$ & $(0.546)$ \\
Most successful & -1.066 & 0.184 \\
& $(4.947)$ & $(0.918)$ \\
Time: Most successful & $12.977^{* * *}$ & $2.407^{* * *}$ \\
& $(4.919)$ & $(0.852)$ \\
Constant & $18.353^{* * *}$ & $5.686^{* * *}$ \\
& $(4.059)$ & $(0.790)$ \\
\hline Observations & 9450 & 9450 \\
Adjusted $\mathrm{R}^{2}$ & & \\
\hline \hline Note: & ${ }^{*} \mathrm{p}<0.1 ;{ }^{* *} \mathrm{p}<0.05 ;{ }^{* * *} \mathrm{p}<0.01$
\end{tabular}

Table 12: Risk taking, pooled model over economic trends. Variables: time - a dummy with value one for period 2-45, and value zero for period 1 .

\begin{tabular}{|c|c|c|c|}
\hline & \multicolumn{3}{|c|}{ Dependent variable: varAllocation } \\
\hline & stable & decrease & increase \\
\hline Age & $\begin{array}{c}0.04 \\
(0.90)\end{array}$ & $\begin{array}{l}-0.67 \\
(0.46)\end{array}$ & $\begin{array}{l}-0.54 \\
(1.04)\end{array}$ \\
\hline Gender & $\begin{array}{c}13.03^{* *} \\
(6.51)\end{array}$ & $\begin{array}{c}9.96 \\
(6.21)\end{array}$ & $\begin{array}{c}15.61^{* * *} \\
(5.86)\end{array}$ \\
\hline Money & $\begin{array}{c}0.01 \\
(0.01)\end{array}$ & $\begin{array}{l}0.01^{*} \\
(0.01)\end{array}$ & $\begin{array}{l}0.004 \\
(0.01)\end{array}$ \\
\hline Most successful & $\begin{array}{c}6.70 \\
(8.41)\end{array}$ & $\begin{array}{l}-3.93 \\
(8.66)\end{array}$ & $\begin{array}{l}-2.06 \\
(8.01)\end{array}$ \\
\hline Period 45 (dummy) & $\begin{array}{c}21.73^{* *} \\
(8.70)\end{array}$ & $\begin{array}{l}10.58 \\
(8.60)\end{array}$ & $\begin{array}{c}8.75 \\
(8.00)\end{array}$ \\
\hline Most successful:Period 45 & $\begin{array}{c}15.52 \\
(11.77)\end{array}$ & $\begin{array}{c}1.83 \\
(12.16)\end{array}$ & $\begin{array}{c}7.67 \\
(11.32)\end{array}$ \\
\hline Constant & $\begin{array}{c}-6.72 \\
(19.70)\end{array}$ & $\begin{array}{l}26.71^{* *} \\
(11.92)\end{array}$ & $\begin{array}{c}18.63 \\
(23.87)\end{array}$ \\
\hline Observations & 132 & 144 & 144 \\
\hline $\mathrm{R}^{2}$ & 0.258 & 0.070 & 0.087 \\
\hline Adjusted $\mathrm{R}^{2}$ & 0.223 & 0.029 & 0.047 \\
\hline
\end{tabular}

Table 13: Difference, Period 1 vs 45, varAllocation. Variables: Period 45 is a dummy variable with value of zero in Period 1 and value one in Period 45. 


\begin{tabular}{|c|c|c|c|}
\hline & \multicolumn{3}{|c|}{ Dependent variable: diffAllocation } \\
\hline & stable & decrease & increase \\
\hline Age & $\begin{array}{l}-0.12 \\
(0.18)\end{array}$ & $\begin{array}{c}-0.18^{*} \\
(0.09)\end{array}$ & $\begin{array}{l}-0.23 \\
(0.22)\end{array}$ \\
\hline Gender & $\begin{array}{c}2.13 \\
(1.32)\end{array}$ & $\begin{array}{c}1.12 \\
(1.26)\end{array}$ & $\begin{array}{l}2.29^{*} \\
(1.22)\end{array}$ \\
\hline Money & $\begin{array}{c}0.003 \\
(0.002)\end{array}$ & $\begin{array}{c}0.002^{*} \\
(0.001)\end{array}$ & $\begin{array}{c}0.001 \\
(0.001)\end{array}$ \\
\hline Most successful & $\begin{array}{c}1.58 \\
(1.70)\end{array}$ & $\begin{array}{l}-0.41 \\
(1.76)\end{array}$ & $\begin{array}{l}-0.09 \\
(1.67)\end{array}$ \\
\hline Period 45 (dummy) & $\begin{array}{c}4.67^{* * *} \\
(1.76)\end{array}$ & $\begin{array}{c}0.83 \\
(1.74)\end{array}$ & $\begin{array}{c}1.61 \\
(1.67)\end{array}$ \\
\hline Most successful:Period 45 & $\begin{array}{c}1.94 \\
(2.39)\end{array}$ & $\begin{array}{c}0.33 \\
(2.46)\end{array}$ & $\begin{array}{c}1.44 \\
(2.36)\end{array}$ \\
\hline Constant & $\begin{array}{c}3.22 \\
(3.99) \\
\end{array}$ & $\begin{array}{c}9.20^{* * *} \\
(2.42)\end{array}$ & $\begin{array}{l}8.82^{*} \\
(4.97) \\
\end{array}$ \\
\hline Observations & 132 & 144 & 144 \\
\hline $\mathrm{R}^{2}$ & 0.227 & 0.045 & 0.065 \\
\hline Adjusted $\mathrm{R}^{2}$ & 0.190 & 0.003 & 0.024 \\
\hline
\end{tabular}

Table 14: Difference, Period 1 vs 45, diffAllocation. Variables: Period 45 is a dummy variable with value of zero in Period 1 and value one in Period 45 


\subsection{Descriptive Plots}

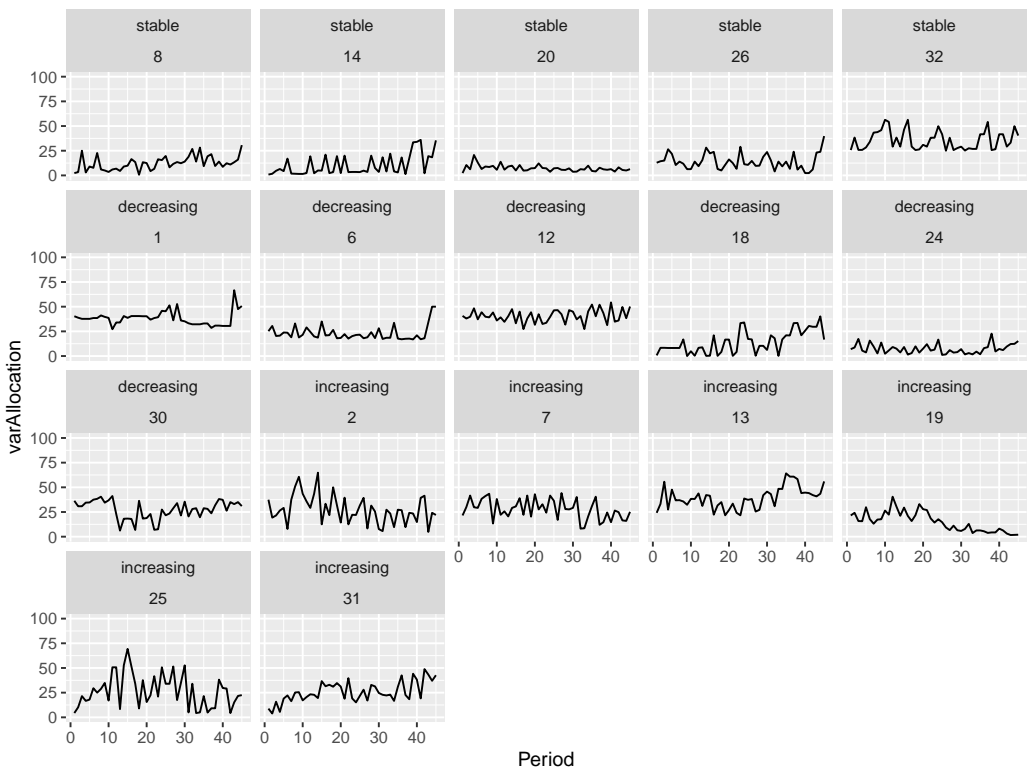

Figure 9: Least successful information manipulation, by economic return trend, for each group (group ID). Vertical axis shows the period of play, horizontal axis the variance of allocation.

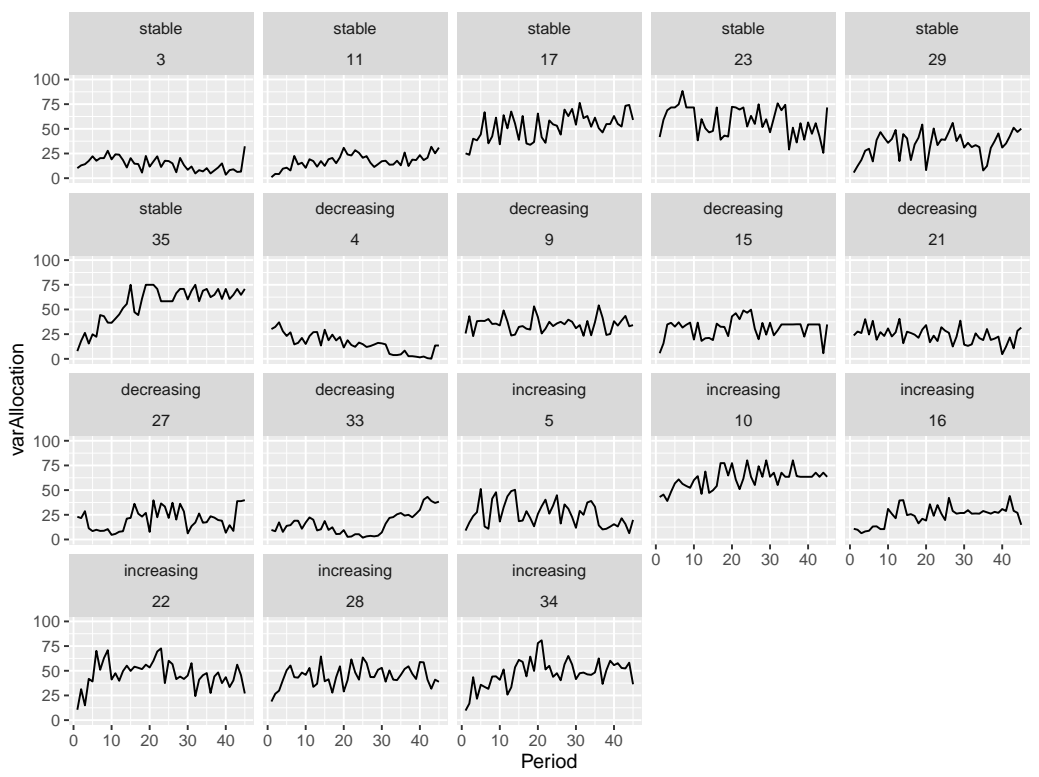

Figure 10: Most successful information manipulation, by economic return trend, for each group (group ID). Vertical axis shows the period of play, horizontal axis the variance of allocation. 
Allgemeine Erklärungen

Wir begrüßen Sie ganz herzlich zu dieser wirtschaftswissenschaftlichen Studie.

Wenn Sie die nachfolgenden Erklärungen genau lesen, dann können Sie - je nach Ihren Entscheidungen - zusätzlich zu den 10 Franken, die Sie als Startgeld für Ihre Teilnahme erhalten, Geld verdienen. Es ist daher sehr wichtig, dass Sie diese Erklärungen genau durchlesen. Wenn Sie Fragen haben, dann richten Sie diese bitte an uns.

Während der Studie ist es Ihnen nicht erlaubt, mit den anderen Teilnehmern der Studie zu sprechen. Die Nichtbeachtung dieser Regel führt zum Ausschluss aus der Studie und allen Zahlungen.

Während der Studie sprechen wir nicht von Franken, sondern von Punkten. Sie können während der Studie Punkte realisieren. Am Ende werden die realisierten Punkte von genau EINER Periode in Franken umgerechnet. Dabei gilt

\section{Punkt $=0.65$ Franken}

Am Ende der heutigen Studie bekommen Sie von uns die verdienten Punkte plus 10 Franken für das Erscheinen bar ausbezahlt.

Auf den folgenden Seiten erläutern wir Ihnen den genauen Ablauf der Studie. Der Einfachheit halber verwenden wir dabei immer nur die männliche Form Teilnehmer; gemeint sind natürlich immer auch Teilnehmerinnen. 


\section{Detaillierte Informationen zum Studienablauf}

Zu Beginn der Studien werden jeweils 6 Teilnehmer dieser Studie einander zufällig als Gruppe zugeteilt. Weder vor noch nach der Studie erfahren Sie die Identität der anderen fünf, Ihnen zugeteilten, Gruppenmitgliedern. Die anderen Gruppenmitglieder erfahren ebenfalls nichts über Ihre Identität.

Alle Gruppenmitglieder erhalten die gleichen Informationen und Instruktionen und sind somit mit der gleichen Entscheidungssituation konfrontiert. Alle Gruppenmitglieder treffen genau 45mal eine Entscheidung. Denken Sie genau nach und versichern Sie sich, dass Sie die Entscheidungssituation gut verstanden haben. Am Ende der Studie wird genau EINE der 45 Entscheidungsperioden per Zufall ausgewählt und jeder Teilnehmer erhält die in jener Periode realisierten Punkte in Franken umgerechnet ausbezahlt.

\section{Die Entscheidungssituation sieht wie folgt aus:}

- In jeder Periode erhalten Sie 20 Start-Punkte. Diese 20 Start-Punkte müssen Sie zwei verschiedenen Feldern, welche wir LINKS und RECHTS nennen, zuordnen.

- In einem der zwei Felder werden die von Ihnen zugeordneten Punkte mit einem Gewinnfaktor $\mathbf{G}$ vervielfacht; wir sprechen hier von dem Gewinnfeld. In dem anderen Feld werden die zugeordneten Punkte halbiert, wir sprechen hier von dem Verlustfeld. Innerhalb einer Periode haben alle Gruppenmitglieder immer den gleichen Gewinnfaktor, von Periode zu Periode kann sich der Gewinnfaktor allerdings möglicherweise ändern.

- Für jede Periode wird ein Feld zufällig als Gewinnfeld und ein Feld zufällig als Verlustfeld ausgewählt. Für alle Gruppenmitglieder wird in einer Periode das gleiche Feld als Gewinnfeld bzw. als Verlustfeld ausgewählt. In jeder Periode haben RECHTS und LINKS eine Chance von $50 \%$ das Gewinnfeld oder das Verlustfeld zu sein. Wenn Sie Ihre Punkte RECHTS und LINKS zuordnen, wissen Sie nicht welches Feld das Gewinnfeld ist. 


\section{Realisierte Punkte pro Periode:}

Alle Start-Punkte, welche sich auf dem Verlustfeld befinden, werden halbiert. Alle Start-Punkte welche sich auf dem Gewinnfeld befinden, werden mit dem Gewinnfaktor vervielfacht. Die realisierten Punkte einer Periode setzen sich aus den Punkten vom Verlustfeld und vom Gewinnfeld zusammen.

Die Punkte, welche Sie pro Periode realisieren können, setzen sich also wie folgt zusammen:

- aus Ihrer Punkte-Zuordnung auf die Felder LINKS und RECHTS

- aus der Bestimmung des Gewinnfeldes und des Verlustfeldes

- aus der Höhe des Gewinnfaktors

Wir geben Ihnen nun zwei hypothetische Rechenbeispiele, wie sich aus den Startpunkten, der Gewinnfeldbestimmung und einer möglichen Punkte-Zuordnung die realisierten Punkte errechnen:

Beispiel 1: Nehmen Sie an, Ihre Zuordnung sei 14 Punkte auf LINKS und somit 6 Punkte auf RECHTS. Der aktuelle Gewinnfaktor sei $G=2$.

- Falls LINKS das Gewinnfeld ist, erhalten Sie in dieser Periode $14 \times 2+6 \times 0.5=$ 31 realisierte Punkte

- Falls RECHTS das Gewinnfeld ist, erhalten Sie in dieser Periode $14 \times 0.5+6 \times 2$ $=19$ realisierte Punkte

Beispiel 2: Nehmen Sie an, Ihre Zuordnung sei 6 Punkte auf LINKS und somit 14 Punkte auf RECHTS. Der aktuelle Gewinnfaktor sei $\mathrm{G}=2$.

- Falls LINKS das Gewinnfeld ist, erhalten Sie in dieser Periode $6 \times 2+14 \times 0.5=$ 19 realisierte Punkte

- Falls RECHTS das Gewinnfeld ist, erhalten Sie in dieser Periode $6 \times 0.5+14 \times 2$ $=31$ realisierte Punkte

\section{Auszahlung:}

Beachten Sie, dass am Ende der Studie nur die realisierten Punkte EINER zufällig ausgewählten Periode in Franken umgerechnet und ausbezahlt werden. Dabei handelt es sich für alle Gruppenmitglieder um die gleiche Periode. Ihre Auszahlung 
setzt sich also aus 10 Franken Startgeld und den in der zufällig ausgewählten Periode von Ihnen realisierten Punkte, umgerechnet in Franken, zusammen.

\section{Detaillierte Informationen zum Studienablauf am Bildschirm}

Betrachten Sie, wie sich die Punkte-Zuordnung für Sie auf dem Bildschirm darstellt.

Der Gewinnfaktor G für Ihre Gruppe ist in dieser Periode 5.0

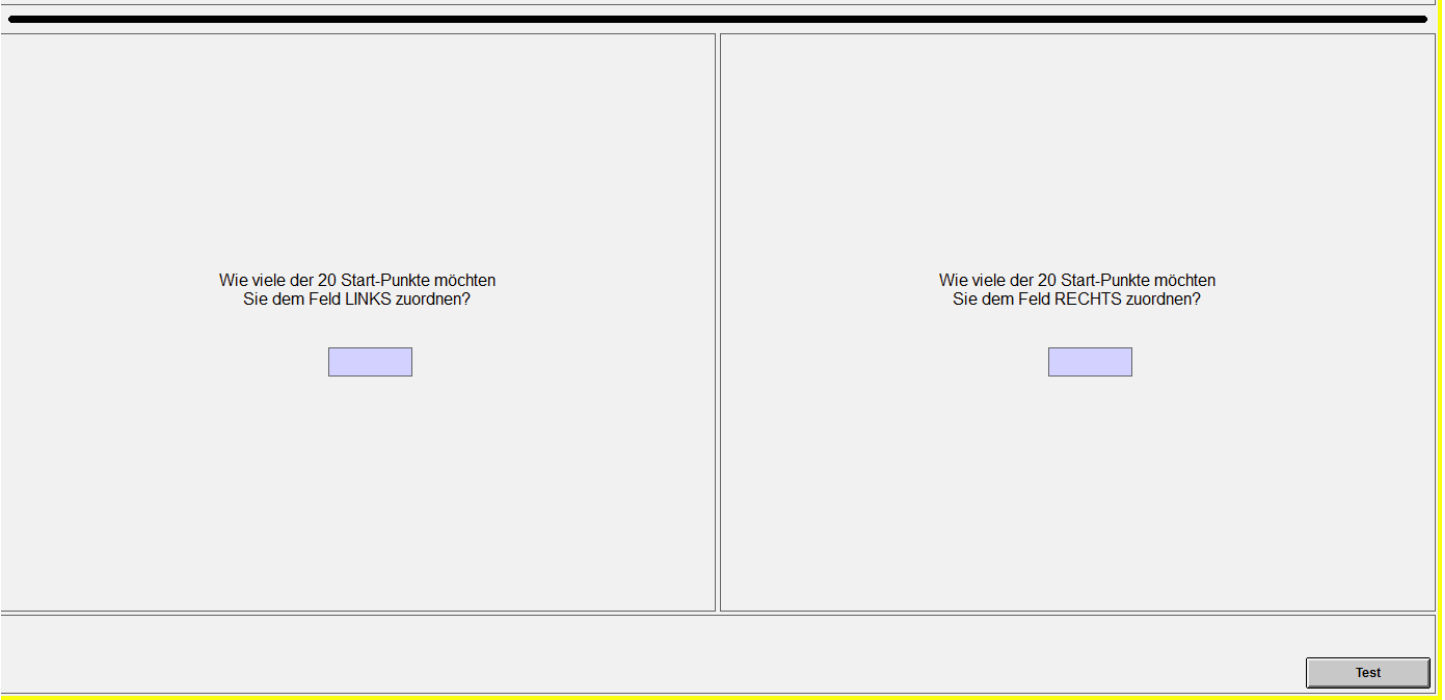

Im oberen Teil des Bildschirms erfahren Sie den aktuellen Gewinnfaktor G, der für diese Periode maßgebend ist. Alle Gruppenmitglieder haben in einer Periode denselben Gewinnfaktor und dasselbe Gewinnfeld. Allerdings kann sich der Gewinnfaktor im Laufe der Studie möglicherweise ändern. Also von Periode zu Periode kann der Gewinnfaktor variieren.

Im unteren Teil des Bildschirms befinden sich zwei aktive Felder, in welche Sie bitte eingeben wie viele der 20 Start-Punkte Sie dem LINKEN Feld zuordnen möchten und wie viele der 20 Start-Punkte Sie dem RECHTEN Feld zuordnen möchten. Sie können jede ganze Zahl zwischen 0 und 20 eingeben. Wichtig ist, dass sich die eingegebenen Punkte zu 20 addieren. Sie können keine Start-Punkte zurück behalten. Wenn die zugeordneten Punkte sich nicht zu 20 addieren, werden Sie darauf hingewiesen und gebeten, die Punkte nochmals einzugeben. Wenn Sie alle Punkte zugeordnet haben, drücken Sie bitte auf die Taste „TEST“. 
Nun sehen Sie auf dem Bildschirm Ihre Punkte-Zuordnung, gemäß Ihrer vorherigen Eingabe. Darüber sehen Sie nochmals den Gewinnfaktor G der aktuellen Periode.

Der Gewinnfaktor G für Ihre Gruppe ist in dieser Periode $\mathbf{5 . 0}$.

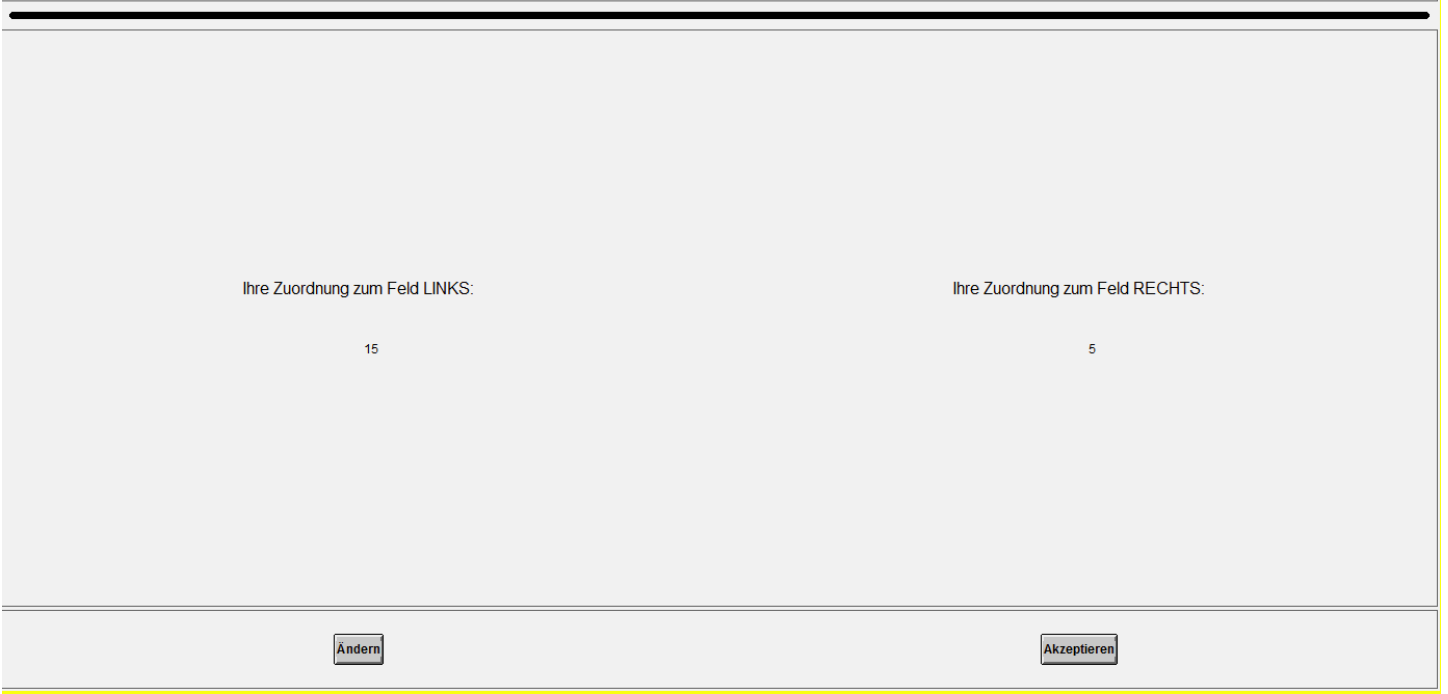

Sie haben nun die Möglichkeit diese Zuordnung allenfalls zu ändern, indem Sie die Taste „ÄNDERN“ klicken, oder Sie können Ihre Zuordnung bestätigen, indem Sie die Taste „AKZEPTIEREN“ klicken. Sie können Ihre Entscheidung mehrere Male ändern, bis zu dem Moment wo Sie die Taste „AKZEPTIEREN“ klicken, dann können Sie Ihre Entscheidung in dieser Periode nicht mehr ändern. Beachten Sie, dass Sie keine Start-Punkte zurückbehalten können, d.h. in jeder Periode müssen Sie sich entscheiden, wie viele Punkte auf den Feldern sein sollen.

Nachdem alle Gruppenmitglieder eine Entscheidung getroffen haben und der Computer entschieden hat welches Feld das Gewinnfeld bzw. das Verlustfeld ist, wird ein neuer Bildschirm angezeigt. 
Nun erfahren Sie wie viele Punkte Sie in dieser Periode, nach Bestimmung des Gewinnfelds und des Verlustfelds, realisiert haben. Die von Ihnen in dieser Periode realisierten Punkte werden im oberen Teil des Bildschirms spezifiziert.

Sie haben in dieser Periode 32.5 Punkte realisiert.

Darunter erhalten Sie Informationen zur Entscheidung und den damit verbundenen realisierten Punkten eines anonymen Gruppenmitglieds (welches auch Sie sein können). Diese Informationen beziehen sich ebenfalls auf diese Periode. Dazu sehen Sie im unteren Teil des Bildschirms auf der linken Seite wie viele Punkte das Mitglied in dieser Periode realisiert hat. Auf der unteren rechten Seite sehen Sie die Punkte-Zuordnung des Mitglieds graphisch wiedergegeben. Sie sehen also, wie das Mitglied die 20 Start-Punkte den Feldern RECHTS und LINKS zugeordnet hat.

Alle Gruppenmitglieder erhalten die gleichen Informationen über ein anonymes Gruppenmitglied in einer Periode. Nachdem Sie und die anderen Gruppenmitglieder diese Informationen mit der Taste „WEITER“ bestätigt haben, beginnt die nächste Periode.

Nachdem Sie die 45 Entscheidungsperioden beendet haben, folgen einige Fragen, welche Sie bitte noch beantworten, bevor die Studie beendet ist und Sie ausbezahlt werden können. 


\section{Zusammenfassung}

- Sie verbleiben während der gesamten Studie (= 45 Perioden) mit denselben 5 Teilnehmern in ein und derselben Gruppe.

- In jeder Periode ordnen Sie 20 Start-Punkte zwei Feldern zu (LINKS und RECHTS). Sie wissen nicht, welches Feld das Gewinnfeld sein wird.

- Nach abgeschlossener Zuordnung der Punkte auf die zwei Felder wird für die gesamte Gruppe ein Feld zufällig als Gewinnfeld und ein Feld zufällig als Verlustfeld bestimmt.

- Der Gewinnfaktor und das Gewinnfeld sind in einer Periode für alle Gruppenmitglieder identisch.

- Der Gewinnfaktor kann sich von Periode zu Periode möglicherweise ändern.

- Sie erfahren nach jeder Periode wie viele Punkte Sie in dieser Periode realisiert haben.

- Zusätzlich erfahren Sie die Punkte-Zuordnung und die Anzahl der realisierten Punkte eines anonymen Gruppenmitglieds (welches auch Sie selbst sein können) in der besagten Periode. Alle Gruppenmitglieder erhalten genau die gleiche Information.

- Die von Ihnen realisierten Punkte einer Periode hängen von Ihrer PunkteZuordnung, dem für die Gruppe realisierten Gewinnfeld und Verlustfeld und vom Gewinnfaktor G der Periode ab.

- Am Ende der Studie wird für die Gruppe als Ganzes eine Periode zufällig ausgewählt. Jedes Gruppenmitglied wird gemäß seiner in dieser Periode realisierten Punkte ausbezahlt. 


\section{Kontrollfragen}

Wenn Sie die Instruktionen komplett verstanden haben, beantworten Sie bitte die Kontrollfragen. Die Studienleiter werden vor dem Beginn der Studie die Richtigkeit Ihrer Antworten kontrollieren. Richtige Antworten bitte ausfüllen oder ankreuzen.

1. Mit wie vielen anderen Teilnehmern sind sie in einer Gruppe?

2. Wie viele Start-Punkte erhalten Sie in jeder Periode?

3. Wovon hängt $\mathrm{ab}$, wie viele Punkte Sie in jeder Periode realisieren?

a. Nur von meiner Zuordnung der Start-Punkte auf das LINKE und das RECHTE Feld.

b. Von meiner Zuordnung der Start-Punkte auf das LINKE und das RECHTE Feld, dem Gewinnfaktor $G$ und davon, welches Feld als Gewinnfeld bestimmt wird.

C. Einzig von meiner Zuordnung der Start-Punkte auf das LINKE und das RECHTE Feld und davon, welches Feld als Gewinnfeld bestimmt wird.

4. Wie viele Entscheidungen müssen Sie in dieser Studie treffen?

5. Wie viele Entscheidungen werden am Ende der Studie ausgezahlt?

6. Wie viele Perioden spielen Sie mit der gleichen Gruppe?

7. Angenommen Sie ordnen 11 Start-Punkte dem Feld RECHTS zu. Der Gewinnfaktor $\mathrm{G}$ sei $\mathrm{G}=2$. Wie viele Punkte realisieren Sie, falls

a. Gewinnfeld $=$ LINKS

b. Gewinnfeld = RECHTS

8. Angenommen Sie ordnen 3 Start-Punkte dem Feld LINKS zu. Der Gewinnfaktor $\mathrm{G}$ sei $\mathrm{G}=4$. Wie viele Punkte realisieren Sie, falls

a. Gewinnfeld $=$ LINKS

b. Gewinnfeld = RECHTS

9. Ist der Gewinnfaktor $\mathrm{G}$ der gleiche für alle Gruppenmitglieder innerhalb einer Periode? 

a. Ja
b. Nein
c. Manchmal ja, manchmal nein.

10. Werden alle Gruppenmitglieder am Ende der Studie für die gleiche zufällig ausgewählte Periode ausgezahlt?
a. Ja
b. Nein

Bitte melden Sie sich indem Sie aufzeigen, wenn Sie alle Fragen beantwortet haben. Ein Studienleiter wird Ihre Antworten kontrollieren. 